\title{
No. 8
}

\section{FEBRERO DE 2019}

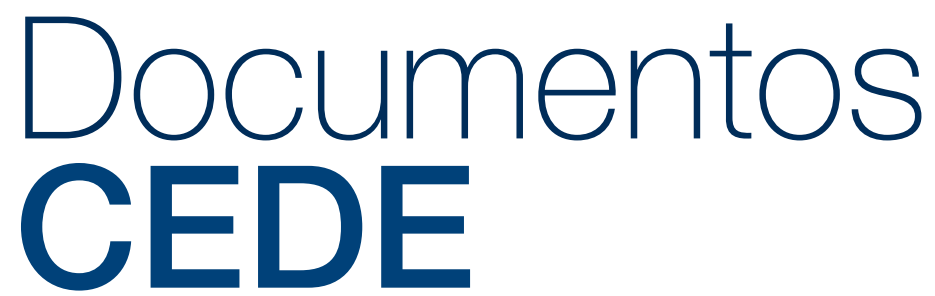

ISSN 1657-7191 Edición electrónica.

The Costs of Bureaucracy and

Corruption at Customs: Evidence from the Computerization of Imports in Colombia

Rachid Laajaj

Marcela Eslava

Tidiane Kinda 


\section{CEDE}

D1)

Facultad de Economía

Serie Documentos Cede, 2019-08

ISSN 1657-7191 Edición electrónica.

Febrero de 2019

(C) 2019, Universidad de los Andes, Facultad de Economía, CEDE. Calle 19A No. 1 - 37 Este, Bloque W.

Bogotá, D. C., Colombia Teléfonos: 3394949- 3394999, extensiones 2400, 2049, 2467

infocede@uniandes.edu.co

http://economia.uniandes.edu.co

Impreso en Colombia - Printed in Colombia

La serie de Documentos de Trabajo CEDE se circula con propósitos de discusión y divulgación. Los artículos no han sido evaluados por pares ni sujetos a ningún tipo de evaluación formal por parte del equipo de trabajo del CEDE.

El contenido de la presente publicación se encuentra protegido por las normas internacionales y nacionales vigentes sobre propiedad intelectual, por tanto su utilización, reproducción, comunicación pública, transformación, distribución, alquiler, préstamo público e importación, total o parcial, en todo o en parte, en formato impreso, digital o en cualquier formato conocido o por conocer, se encuentran prohibidos, y sólo serán lícitos en la medida en que se cuente con la autorización previa y expresa por escrito del autor o titular. Las limitaciones y excepciones al Derecho de Autor, sólo serán aplicables en la medida en que se den dentro de los denominados Usos Honrados (Fair use), estén previa y expresamente establecidas, no causen un grave e injustificado perjuicio a los intereses legítimos del autor o titular, y no atenten contra la normal explotación de la obra.

Universidad de los Andes | Vigilada Mineducación

Reconocimiento como Universidad: Decreto 1297 del 30 de mayo de 1964. Reconocimiento personería jurídica: Resolución 28 del 23 de febrero de 1949 Minjusticia. 


\title{
The Costs of Bureaucracy and Corruption at Customs: Evidence from the Computerization of Imports in Colombia
}

\author{
Rachid Laajaj* Marcela Eslava ${ }^{\dagger} \&$ Tidiane Kinda ${ }^{\frac{8}{*}}$
}

\begin{abstract}
Customs face a difficult tradeoff between, on one side, collecting tariff revenues and preventing smuggling, and on the other side, avoiding creating additional barriers to trade. They also tend to concentrate discretionary power in the hands of officials whose decisions can bear high costs for the firms, creating room for rent extraction. In this context, information technologies can limit direct interactions, reduce transaction costs and allow local businesses to better take advantage of the benefits of international trade. We assess the effects of the computerization of import transactions on plants' growth in Colombia. The reform occurred sequentially in the different customs between 2000 and 2005, allowing us to use a triple-difference strategy, comparing the change in outcome variables of plants that were importing before the beginning of the reform, to the one of firms that were not importing (less likely to be affected by changes at customs). We find that the computerization of imports led to an increase of $6 \log$ points in the firms' value added along with consequent increases in employment, productivity and tax collection. However, it generated winners (importing firms) and losers (non-importing firms). Our investigation of the channels reveals a reduction in corruption judiciary cases at treated customs, as well as a reduction of time to clear customs and its unpredictability. Our results support growing evidence of the high potential of proper use of information technologies to improve efficiency and tackle corruption in public administration with important consequences for the economy.
\end{abstract}

JEL codes D73, F61,O12, K42

Key words: imports, customs, firm, corruption bureaucracy

\footnotetext{
*University of Los Andes, corresponding author r.laajaj@uniandes.edu.co

${ }^{\dagger}$ University of Los Andes

¥International Monetary Fund

$\S$ We thank Ernesto Dal Bó, Claudio Ferraz, Frederico Finan, Daniel Lederman, Christian Volpe Martincus for useful comments. We are also grateful to seminar participants at the ABCDE 2018 at the World Bank, the CAF 2016 Productivity conference at Universidad Torcuato di Tella; the 4th DIAL Development Conference in Paris Dauphine; the 16th Journées Louis-André Gérard-Varet at the at the Aix-Marseille School of Economics; the 2018 meeting of LACEA's Trade and Integration Network; the 2018 meeting of the LACEA RIDGE Political Economy Group, and the University of Los Andes. We thank Daniel Espinoza Castro for his relentless work as a research assistant. We are grateful to DANE and DIAN for making their data available to us, and to CAF and Universidad de Los Andes for generously provided funding.
} 


\title{
Costos de la burocracia y la corrupción aduanera: evidencia a partir de la sistematización de las aduanas colombianas
}

\author{
Rachid Laajaj, Marcela Eslava \& Tidiane Kinda
}

\begin{abstract}
Las administraciones aduaneras enfrentan la difícil tarea de balancear la necesidad de prevenir el contrabando y generar ingresos fiscales con aquella de minimizar la carga burocrática sobre las empresas. El poder discrecional concentrado en las manos de los agentes aduaneros les da la oportunidad de extraer rentas de los importadores. La incorporación de nuevas tecnologías de información puede ayudar a paliar estos costos del proceso aduanero. En este artículo estudiamos el efecto de la computarización del proceso aduanero sobre el desempeño de las plantas manufactureras en Colombia. Utilizamos una estrategia de triples diferencias que aprovecha dos hechos: 1) que la reforma se implementó de manera secuencial en las distintas aduanas del país a partir del año 2000, y 2) que su efecto debe ser diferencial dependiendo del grado de vocación importadora de la planta. Los resultados indican una ganancia de 6 puntos logarítmicos en el valor agregado, con ganancias asociadas en productividad, empleo e ingresos aduaneros. Encontramos que estas ganancias están en parte explicadas por una reducción del tiempo de la carga en aduana, así como menor corrupción en las aduanas. Los importadores fueron ganadores netos mientras lo no importadores perdieron. Más allá de mostrar los beneficios de la computarización en las aduanas, nuestros resultados señalan el alto potencial de un uso adecuado de las tecnologías de la información para reducir las pérdidas de eficiencia asociadas a la burocracia.
\end{abstract}

codigos JEL: D73, F61,O12, K42

Palabras claves: importaciones, aduana, firma, corrupción, burocracia 


\section{Introduction}

Studies show that imports by firms can increase their efficiency and the quality of inputs and outputs, even though their effect on domestic firm size is ambiguous because the productivity kick associated with imports is balanced-out by a contraction in revenues via increased competition ${ }^{1}$. Though potential gains from trade have been frequently studied in the context of reforms that reduced tariffs, tariffs are by no means the only or more important barrier faced by firms in international trade. In most of the developing world, for instance, firms responding to the World Business Environment Surveys identify customs and trade regulations as the second most serious constraint on private sector development (Batra et al., 2003). Customs are recognized as a hub for bureaucracy and corruption in developing countries, despite (or perhaps because of) the high stakes involved in their efficiency. Using firm level surveys in Uganda, Svensson (2003) finds that a one percentage point increase in bribes reduces annual firm growth by three percentage points, which is three times the negative impact as the one of equivalent formal taxes. Similar channels may clearly operate in the context of customs, both in relation to bribes and other obstacles that reduce customs efficiency. If this is the case, then administrative reforms that reduce these constraints at customs may bring large benefits to the economy, perhaps even in excess of the benefits attached to trade liberalization. Information technologies likely play a particularly important role in tackling administrative constraints through their potential to increase efficiency and transparency. Despite all this, there is, to the best of our knowledge, no causal evidence on the effect of the use of information technologies at customs on firms' growth and productivity.

In non-modernized customs, controls and revenue collections rely mostly on physical inspections. Even in the absence of corruption, it is challenging to perform the necessary controls on transactions without hampering trade. Moreover, customs officers have significant discretion to stop cargo, and a broad bureaucratic toolkit from which to draw on to justify delays and unanticipated hurdles Sequeira (2015). Since tax rates vary by type of good, goods may be misclassified, intentionally or not, influencing the amount to be charged. This discretionary power creates an opportunity for rent extraction, which can act as an additional tax for the firms.

In this article, we examine the effects of the computerization of customs procedures for imports on the economic activity of manufacturing firms in Colombia. The reform, implemented by the Colombian customs and tax authority DIAN (Spanish acronym for Direction of Taxes and National Customs), systematized the requirements at each step of the imports declaration and allowed the firm to complete almost every procedure online rather than in person, thus limiting the interaction with customs agents. The need for physical inspections was reduced, and the decision to undertake such inspection, previously at the discretion of the customs agent, became taken by a computer, triggered by risk profiles and suspicious inconsistencies between the declarations of the foreign exporting firm, the importing firm, the transporter, the warehouse, and the bank where the payment of tariffs must be made. These changes

\footnotetext{
${ }^{1}$ For instance, see Halpern et al., 2011 for Armenia, Amiti and Konings, 2007 for Indonesia, Kugler and Verhoogen, 2009 and Fieler et al., 2018 for Colombia
} 
reduced bureaucratic hurdles, while maintaining or even increasing the ability to apply the necessary controls and tariff collection. Clearly, the computerization brings multiple changes in procedures and responsibilities of the customs officials. The effects of the reform estimated in this paper reflect the entire set of concurring changes that were made feasible by the technology.

The limited capacity of the team that put the computerization in place led to a sequential implementation of the reform across the 26 customs posts. From the beginning of 2000 to the end of 2005, customs moved from none to over $99 \%$ transactions computerized nationally, sequentially adding custom posts to the computerized system. Figure 1 presents the share of imports declared online in Colombia during the period of study, while Figure 2 presents the same statistic by port for the 15 largest customs posts in Colombia. Figure 2 indicates that, in each post, computerization jumps from none to almost all transactions being computerized, and that the year of computerization varies by custom post. This sequential implementation, together with the rich data offer a unique opportunity to isolate the effects of the reform on the economy. Our database includes yearly panel data on all non-micro manufacturing plants in Colombia, covering 1997 to 2009, spanning the pre- and post-reform periods. We combine it with customs administrative data on all imports transactions going through the 26 Colombian customs posts during this period. Plants are matched with customs posts based on the frequency with which, prior to the reform, plants from the same municipality imported through a given customs post. We consider that an importing plant is "treated" once the assigned customs post underwent the computerization.

We use a triple difference, building on the fact that the reform occurred sequentially in the different customs of Colombia between 2000 and 2005, and also that importing plants should be more exposed to the treatment than non importing ones.A plant is considered "exposed" to the treatment if the firm that owns the plant was an importer before any of the computerization waves started. Our approach estimates whether, in the years following the reform of the associated customs post, importing firms grew faster than non-importing firms. The underlying identification hypothesis would be violated if the DIAN prioritized areas with greater difference in growth potential between importers and non-importers, however our parallel trend analysis do not show evidence of such violation before the reform. This strategy allows the incorporation of year dummies,to control for concurrent changes in taxation or other policies implemented at the country level. Furthermore, exports were computerized a few years after imports and followed a different calendar. Hence, our results should be interpreted as the effects of the computerization of imports only rather than all trade flows.

We find that the computerization of customs led to a gradual and substantial increase in the importing manufacturing plants' productivity and economic activity. The value added of importing firms increased by $6.5 \log$ points, while their number of workers increased by $5.7 \log$ points and Total Factor Productivity increased by $1.3 \log$ points. We also find evidence of negative effects on the growth of non-importing firms, for which the negative competition effect likely overcomes potential positive effects through post-reform input imports. The net effect on the manufacturing sector in Colombia is an increase of about $6 \%$ of all the non-micro enterprises. An increase that is mostly driven by small to medium sized firms. 
Additional estimations allow us to shed light on the channels behind these results. Using double difference estimations, we find that the computerization led to a large increase in the number of imports going by treated ports, and in the total annual value of imports declared. The effective tax rate on imports' transactions shows no significant change, but total taxes collected at customs increased significantly as a result of the increase in the tax base. In the meantime, the number of days to clear customs was reduced by about $8 \%$. It indicates that the reform was effective at facilitating imports, but also that the change is small in magnitude, perhaps as a result of the reorientation of imports. We find an increase in transportation costs of merchandises reaching treated customs, suggesting that firms are willing to travel further in order to go through a computerized customs post. This revealed preference is in line with findings by Sequeira and Djankov (2014), who show that firms in Southern Africa are willing to travel significantly longer distances in order to go through a less corrupt port.

Smoking-gun evidence of changes in corruption is always challenging. we also find evidence that points towards reduced corruption being one of the channels behind the increase in economic activity that resulted from the reform. First, we summarize the abundant anecdotal evidence from the internal documentation of the DIAN, which explicitly points to tackling corruption as a primary goal of the reform, and details how the reform was expected to sever many of the lines that made import transactions possible preys to corruption, in particular the discretionary power of on-the-ground customs officials. Second, in line with this reduction of discretion at ports, we find that the reform significantly increased predictability of the number of days of the customs transactions. Third, we find that the reform significantly reduced the discrepancies between the amount of import taxes due and the one paid, according to the customs declaration, in particular for large firms. Finally, using data from the Procurador General de la Nación (the General Prosecutor), we find that the computerization of a port is followed by a significant drop in the number of judiciary cases related to corruption at DIAN in its municipality. All together, these pieces bring clear indications that a reduction of corruption is part of the channel and contributes to explaining the magnitude of the impact.

Analysts have argued that corruption at customs may help or hurt firms engaging in import transactions, depending on whether it is "collusive" or "coercive" (Sequeira, 2015). Sequeira (2016) finds that, in Southern Africa, small bribes allowed firms that pay them to obtain significant reductions of tariffs, which implied that collusive corruption is dominant in this context. We find that both coercion and collusion were occurring before the reform, but the large positive effects of the reform point toward a predominantly coercive corruption. Our results are consistent with research that point at corruption acting as a tax on the economy. For instance Wei (2000) analyzes data from 45 host countries and conclude that an increase in the corruption level from the one of Singapore to the one of Mexico would discourage inward FDI by as much as a twenty percentage points raise in tax.

The Arusha Declaration of the World Customs Organization Concerning Good Governance and Integrity in Customs (1993) puts automation of transactions in customs as one of the key pillars to reduce corruption. Computerization of customs transactions has been adopted by the vast majority of OECD 
countries and is widely recommended by international organizations (such as the IMF, UNCTAD or the Inter-American Center for Tax Administrators) which have invested in the provision of training and software for the computerization of customs transactions in middle and low income countries. Numerous case studies document the benefits and challenges of customs computerization (De Wulf and Sokol, 2004; Engman, 2005). Others have analyzed the role of customs infrastructure or delays in trade facilitation (Clark et al., 2004; Dollar et al., 2003; Guasch and Kogan, 2001). Also Yang (2006) shows that developing countries hiring private firms for pre-shipment inspections to reduce fraud at imports significantly increased their tariff revenues. However, to the best of our knowledge, there are no causal evidence of the impact of the use of information technologies at customs on firm level outcomes.

This paper is related to the vast literature that aims at understanding how the removal of tariff and non-tariff barriers to trade affects the economy (Sachs et al., 1995; Dollar et al., 2003; Wacziarg and Welch, 2008; Rodrik et al., 2004) More recently, firm level studies have emphasized the benefits of trade liberalization for labor productivity and growth in the Canada-US free trade agreement (Trefler, 2004), Armenia (Halpern et al., 2011) and Indonesia (Amiti and Konings, 2007). Using the same Colombian manufacturing plants census data as the one used in this paper, Kugler and Verhoogen (2009), Eslava et al. (2015) and Fieler et al. (2018) provide evidence that, at least in the 1990s, inputs on the import market are higher quality than the ones on the domestic market. They are used by firms that are larger and more productive; and allow importing firms to produce better outputs and sell them to other local firms, who in turn can also improve their quality. Reduced costs of importing also lead to greater competitive pressures on local producers, which have been found to increase the productivity of firms more exposed to external competition. While increased productivity generates incentives to increase scale, these incentives may be overcome by the depressing pressure that competition exerts on a firm's scale . Fieler et al. (2018), in fact, suggest that this was the case in the Colombian trade liberalization of the early 1990s. To this abundant body of literature on the effect of trade on firms, we add evidence on the potential effectiveness of reforms on the administrative margin of trade policy, which can be a win-win, both on fiscal and economic consequences. It may nonetheless generate losers among non-importing firms and customs agents, which may resist the reform. Compared to a change in tariff, the implementation of such a reform trades external political challenges for internal ones.

This paper also contributes to the research on corruption in developing countries. It has been shown that inefficient institutions are one of the distinguishing characteristics of developing countries and play an important role in the persistence of poverty ((Mauro, 1995; La Porta et al., 1999, 2000)). Bureaucracy and corruption have been found to take a toll on development that goes beyond simple transfers from the business sector to the corrupt officials. It can discourage investment (Samphantharak and Malesky, 2008) and human capital accumulation (Ferraz et al., 2012; Reinikka and Svensson, 2004), lead to the misallocation of capital (Khwaja and Mian, 2005), or talents (Ebeke et al., 2015). It also affects public expenditures Olken (2006), and harms the government's ability to correct externalities (Olken and Barron, 
$2009)^{2}$. Within this corruption literature, our research most closely relates to the growing literature on the potential of information technologies to improve efficiency and reduce corruption (Giné et al., 2012; Lewis-Faupel et al., 2016; Banerjee et al., 2016; Muralidharan et al., 2016). It complements it with primary evidence of the effect on an intervention at the customs level.

Our results estimate the magnitude of the costs of bureaucracy and corruption at customs, but also provide an example of a successful, practical solution to tackle this complex issue through a proper use of informational technologies. The cost of the computerization of imports that we evaluate (about 6 million USD) is dwarfed by the observed benefits on the economy. Given our results, the Colombian computerization reform can serve as an example for a large number of low income countries with old-style customs, in particular in sub-Saharan Africa. Of course, applicability in different contexts is not granted, given the need for political will and institutional capacity to adopt and successfully implement this type of reforms (De Wulf and Sokol (2004)). In fact its lessons are also applicable to Colombia, where customs underwent large improvements in the beginning of the century, but today, still lag behind many middle income countries, and are in urgent need for a major upgrade.

\section{Context and the Computarization of Customs in Colombia}

\subsection{Context}

From 1997 to 2005, Colombian's GDP per capita grew on average by 3.3\% per year. Trade openness as a share of GDP slightly increased from about $35 \%$ to $38 \%$ while the share of the manufacturing sector remained stable around $14 \%$ of the economy. ${ }^{3}$. Colombia has its share of corruption and governance issues fueled, among other things, by money from narco-traficking. However, during the period of the computerization that we examine, its ranking according to the World Government Indicators increased from 34th percentile of countries for which the data is available in 2000 to the 41 st percentile in 2006 (and reaching the 45th percentile in 2015) with the greatest improvements seen in the Rule of Law and Control of Corruption indexes. The modernization of customs was one of the reforms taken by the Colombian Government during this period in order to tackle corruption. To illustrate this, Appendix Figure 1 shows that, according to our customs data, the average customs clearance time for importation went down from about 17 days in 1995 to a bit less than 10 days in 2014. The general improvement in Colombian customs facilitation, trade and institutions are consistent with the main findings of this paper, and raise the importance of drawing lessons from policies that may have contributed to this progress.

\footnotetext{
${ }^{2}$ For an overview of the empirical literature on corruption in developing countries see Olken and Pande (2012)

${ }^{3}$ World Bank statistics available at https://data.worldbank.org/
} 


\subsection{Description of the Customs Reform and Qualitative Evidence}

The decision to focus on the computerization originated from discussions with the management and operations staff at DIAN. When asked about the changes that were most influential to tackle corruption and facilitate the transits for the firms, the computerization was brought forward as a game changer, allowing customs to facilitate transactions and better monitor them. The program was named Siglo XXI, and its implementation started in 2000. ${ }^{4}$ The computerization occurred in different customs posts at different periods, as illustrated in figure 2. This staggered timing is due to the limited capacity of the team implementing the program, and the capacity building required with the implementation at each customs post.

The new system allowed users to declare their imports online rather than at arrival at the customs, facilitating and speeding up the process. It was expected to reduce large economic costs due to the bureaucracy and immobilization of merchandises at imports. DIAN's internal documentation, however, makes it clear that the reform goes beyond a digitization of the declaration. It emphasizes a broad "need to bring the technological strategy in line with developments in regulation and procedures". For this reason, this study must be interpreted as an evaluation of the entire reform that was made possible by the computerization.

The DIAN share internal documents describing the reform. The most comprehensive document, produced in 2001, is titled "Advances in the Control of Corruption Through the Customs System Siglo XXI" displaying its central objective. It includes a summary table with remarkably detailed accounts of the flaws of the existing system that left room for corruption, and how they would be addressed by the reform. We present key features of the reform, as described by the internal documentation:

- Before the reform, "The only criteria to inspect the charge was the judgment of the customs inspector", but after the reform, "the possibility of corruption acts has been diminished since the transporter interacts with the customs officer only when the computer system calls for such interaction"

- Prior to the reform, there was a risk of a cargo not being presented to the customs office, or that the quantities or values were under-reported. After the reform, customs are automatically informed of deliveries.

- The "risk that the customs inspector declares conformity between the cargo manifest and the physical cargo when there is a difference that should cause its apprehension" was reduced by the "full control and identification of the actors who perform each one of the checks". That is, the new system generated traceability and better accountability from the customs officers, who can be concerned about a "risk that the customs authority verifies the correspondence between the form and the real cargo".

\footnotetext{
${ }^{4}$ DIAN started the development of Siglo XXI in 1997 with the project "Sistema Global de Información y Mejoramiento de la Gestión Aduanera Siglo XXI"
} 
- "In the previous scheme, there was no transmission of the message with payment notification by the Bank, which generated multiple problems that were difficult to detect before the release of the cargo (falsifications, adulteration, etc.)" whereas in the new scheme, the DIAN receives the online confirmation of payments and "once the payment is made, the release request is executed without any intervention by customs authorities ", "about $86 \%$ of the merchandise obtain automatic release" compared to 30 to $40 \%$ before the reform.

- Siglo XXI allowed the instantaneous registration and comparison across declarations by the transporter, the importer, the warehouse, and the bank. "Discretion by the officials for the selection of documents for inspection purposes is completely eliminated".

- The physical or documentary inspection processes in the new system are triggered by inconsistencies in the declarations and risk profiles rather than arbitrary decisions of customs officers. "In the new scheme, customs executes physical inspections to no more than $9 \%$ of the documents. This is an improvement since, before, the rate over 50\%." Automatic risk profiles were already in place in 2001 , but many additional elements were expected to be progressively incorporated.

- Efficiency gains from the rapid processing of information and "avoiding duplication of processes (such as typing) for users"

- "Tools are provided so that users can do management control of their processes"

The report, written in 2001, after implementation had started in Bogota, draws a number of conclusions on its effects. The first set of benefits relates to an increase in convenience for the importers due to the reduction in bureaucracy. "With the exception of the physical inspection and payment, all the processes related to the declaration's obligations can be developed from its management center through the Internet". As argued by the documentation, the time to clear customs was reduced and the reform "reduce[d] the possibility of errors that imply indirect costs to the user such as onerous sanctions or delays in the procedures". All these benefits would occur even in the absence of corruption under the initial system, simply from the improvements in efficiency allowed by the better management of information offered by the technology.

Another set of benefits described by the internal documentation clearly points towards a reduction in corruption. It highlights a "decrease of discretion in the exercise of the customs function, through the automation of a large part of the controls and the exercise of physical reviews based on risk profiles, and with the support of the computer application, providing greater transparency in the procedures" as well as an "improvement in the control of the fulfillment of the obligations by the customs authority, and specifically those of declaration and payment of taxes". Mistrust in the activities performed by some customs agents before the reform is evident in these words, as is the desire both to limit their direct interactions with the importers and, when interactions are necessary, to make them more transparent and traceable. The documentation explicitly states the view that the reform resulted in a "decrease in the 
degree of corruption, evidenced by the reduction of complaints by customs users and their associations". The program may have contributed to the $17.75 \%$ increase in the collection of customs taxes in Bogota in its first year of implementation, although the authors also argue that such increase may be partly due to a recovery from a bad year in 1999.

These qualitative insights from DIAN's internal reports help guide our empirical analysis. They suggest that we should expect an increase in the number of transactions (if the reform reduced outright smuggling) and in imported amounts (if it reduced under-declarations). We will also compare the amounts actually paid by the importers to the amount due according to the data. Discrepancies are a sign that may reflect fraud made easier by a lack of communication with the banks, as mentioned above. Facilitation should also be reflected by a reduction in the duration to pass the customs. This facilitation and reduction of corruption should lead to a preference for reformed customs which should be reflected by an increase in imports through reformed customs. The switch from discretionary power to a stricter application of the rules may be reflected in a change in sanctions applied to the importers when they did not comply with the procedures or delays. Finally, another insight from discussions and documentation is that risk profiling went from relatively crude to complex algorithms, as the administration improved its ability to make use of the available data to identify risky transactions. Hence the benefits of the reform should be progressive over the years following its implementation.

\section{Data and variable definitions}

This section describes the four databases used for the analysis, and how we combined it. To keep in mind how the data is used, when looking at the impact of the computerization on firm level outcomes, we use a triple difference strategy that allows the change in economic outcomes to be affected by the timing of the computerization at the most relevant port but also by the exposure of the firm to the reform, which depends on whether it is an importer before any of the reforms. We also analyze the channels using data collected at customs, data on corruption judiciary cases, and data from the International Trade Statistics Database. All our data cover the study period of 1997 to 2008, from 3 years prior to the first computerization to 3 years after the last computerization.

\subsection{Data Description}

This paper combines three rich databases. First, we use the imports transaction database from DIAN (the Colombian customs authority, by its acronym in Spanish), which covers all import transactions. This database gathers about 1,000,000 import transactions per year from about 56,000 firms. For each transaction, it provides information about the type of good that is imported, its quantity, value, destination, origin, and the taxes to be paid in association with the transaction. It also includes the dates of arrival and clearance which allows us to calculate the clearance time for each transaction. We were 
able to recover whether each transaction was done manually or by computer. Panel B of Table 1 lists the variables from the customs database that we use for our analysis.

Our primary outcome variables come from the the Annual Manufacturing Survey (EAM) provided by the official Colombian statistical agency (DANE), a rich yearly panel data on about 6,000 manufacturing plants. The database covers all manufacturing plants with at least 10 employees in the country, or with a level of annual production above a certain limit (worth about USD 150,000 in 2017). Once we keep only plants available throughout all years of the study period, we are left with 3,478 plants. The results remain highly consistent if we include firms with years of missing information. The EAM data contains annual information on value added, sales, inputs, labor, capital and other standard indicators of the economic activity of the plants. We also calculate, based on these indicators, measures of productivity, in particular sales per worker and Total Factor Productivity. Table 1A provides a description of the variables that we computed from the EAM data. Plant-level information from EAM is complemented with the DIAN information for the purpose of assigning a relevant customs post to any given plant for the pre-refom period. This process is described in detail in the following subsection.

In order to test whether the degree of corruption was affected by the reform, we also use data from the Information System of Registration of Sanctions and Causes of Dismissal (in Spanish Sistema de Información de Registro de sanciones y causas de Inhabilidad), which registers the executed and notified decisions sent to the Attorney General's Office by the competent authorities. This database includes all disciplinary and legal violations in the public sector that that were investigated by this Office. The information about each case includes the municipality where the violation occurred, the public agency to which accused officials are affiliated, the outcome of the case (guilty or not, and the disciplinary or legal sanctions), and a description of the violation. We construct a data set that counts, by municipality and year, the number of cases related to corruption by officials affiliated with DIAN and those by officials affiliated to other agencies (which we use as a control). We labeled the following types of violations as corruption-related: budget violations, contractual violations, administrative violations and violations with criminal connotations. We use both unweighted counts of judiciary cases and a weighted counts obtained by Principal Component Analysis across different type of violations. It is worth pointing that over the years of study there are 7042 violations related to corruption, of which only 37 cases involve an employee of the DIAN. This small number of cases raises a limitation of the approach, hence it is the combination of evidence that unveils the role of corruption in the economic impacts that are observed.

\subsection{Plants exposure to the Treatment and their Assignment to Customs Posts}

In this subsection, we explain how we match plants with customs posts and our definition of treatment

and exposure. Both were done with the intent to minimize potential concerns of endogeneity. In our baseline specification, we assign each plant to the customs post through which imports by firms in the 
plant's municipality were most likely to go, in the pre-reform period. To do this we first calculated, for each firm in the DIAN database, the share of the value of its imports that came through each port in the pre-reform period. We then averaged this share across firms in the same municipality, ranked the resulting average for each municipality over ports, and assigned to each municipality the port to which the highest share was associated. Finally, we associated each plant in the EAM database to the port assigned to its municipality in the previous step. The rules of assignment use imports 1) prior to the reform, and 2) at the municipality level, which should both minimize risks of endogeneity. In section 4.4 we explore the robustness of our results to alternative methods of assignments of plants to customs.

Once a plant has been assigned to a port, each plant and year is considered as "treated" if the customs post assigned to the plant had undergone computerization at that point in time. We label a customs post as computerized if over $80 \%$ of imports were declared by computer, rather than manually. ${ }^{5}$ Notice from Figure 2, that in each customs posts, the switch from manual to digital imports almost always rapidly jumped from 0 to almost $100 \%$ of imports and then remained around $100 \%$, hence it makes sense to consider this as a discontinuous treatment, and it is not sensitive to setting the cutoff at $80 \%{ }^{6}$

Finally, a plant is considered as exposed to the treatment if the firm to which the plant belongs carried any import transaction in 1997-1999. We, again, define exposure based on the pre-reform period so that the exposure status is not affected by the computerization of its corresponding custom. Besides this, the firm-level merge between the DIAN and the EAM database also allows us to assign to each plant in the EAM, outcomes registered by DIAN, related to importing by its owning firm: value of imports, taxes due and paid, etc. Because the merge is only possible at the firm level, rather than the plant level, the interpretation must take into account the fact that we observe import transactions for the plant added to those by other plants owned by the same firm, and including non-manufacturing activity of the firm. ${ }^{7}$

\section{Effects of the computerization on plant level economic out- comes}

This section presents the analysis of the effect of the reform on plant outcomes. We begin by presenting the baseline strategy, followed by the corresponding results. We then present extensions and validation tests.

\footnotetext{
${ }^{5} \mathrm{~A}$ code in the DIAN database allows us to identify whether the declaration is manual or computerized. We thank DIAN's staff for pointing us to this code

${ }^{6}$ Bogota, which was the first customs to implement the computerization, is the one exception with a rapid raise to about $86 \%$ of transactions, but reaching $100 \%$ only 2 years after the beginning of the computerization. Still the initial rapid raise is enough to consider Bogota as treated in year 2001, and Table A2 shows that the results are robust to the exclusion of municipalities one by one.

${ }^{7}$ The merge between EAM and DIAN is possible by the presence of tax identifiers for firms in both databases. However, access to such identifiers is subject to even stricter confidentiality restrictions than the rest of the EAM.
} 


\subsection{Main Specification}

The methodology builds on the fact that computerization occurred in different customs posts at different periods, because of the limited capacity of the team that trained the customs agents to use the new program. The timing is certainly correlated with the capacity of each customs post, itself correlated with characteristics of the firms most likely to go through the customs. To address this issue, we use a triple difference strategy, exploiting both the staggered timing of the computerization and the firms' degree of exposure to the reform, which is defined by their prior importation status. In particular, our main regression can be written as:

$$
Y_{p c t}=\beta T_{c t} * I_{p}+\delta T_{c t}+X_{p c t} \lambda+\theta_{p}+\gamma_{t}+\varepsilon_{p c t}
$$

where each observation corresponds to a plant year combination. $Y_{p c t}$ is the outcome of interest in year $t$ of plant $p$ associated to customs post $c$. The outcomes of interest are measures of the economic activity of the pant. $T_{c t}$ is a dummy equal to 1 if, in customs $c$, more than $80 \%$ of imports were digital at year $t . I_{p}$ is our indicator for exposure to the treatment: a plant level dummy, equal to one if the plant imported at least once between 1997 and 1999 before any treatment. $\theta_{p}$ are plant level fixed effects and $\gamma_{t}$ are year fixed effects. $X_{p c t}$ is a set of additional controls, composed of the log of the value added in 1999 interacted with year dummies, and of the value of transactions in the associated customs post in 1999 interacted with year dummies. Such controls are essential to take into account the fact that initial differences in customs and firms characteristics can drive differences in changes over time. ${ }^{8}$

Note that we do not control for $I_{p}$ alone because it is already captured by the plant dummies. $\varepsilon_{p c t}$ is the error term, clustered at the customs level to account for possible customs level shocks. Because the number of clusters is relatively small (26 customs), we also present the wild bootstrap p-values following Cameron et al. (2008).

$\beta$ is the triple difference estimator of the effect of the reform on exposed plants compared to non exposed plants. It captures the difference in the change in the outcome variable between importing firms and non importing firms that results from the computerization of the assigned customs.

However, non exposed plants may be indirectly affected by computerization. A positive effect can result from the indirect access to cheaper and higher quality inputs and a negative one can be due to the increased competition from importers. Hence we are also interested in $\delta$, which is a measure of the change in outcome $Y$ that occurs among non exposed plants at the time when imports became computerized in the corresponding customs post. Finally, our estimation of the computerization on exposed firms is given by $\beta+\delta$, hence all regressions show the $\mathrm{p}$-value that tests the significance of this sum. $\beta$ is estimated by a triple difference while the estimations of $\beta$ and $\beta+\delta$ are equivalent to a double difference.

The identifying assumption of the double difference is that there is no systematic relationship between

\footnotetext{
${ }^{8}$ In particular exposed customs are on average substantially larger than non exposed customs. To address this 1) add the controls described above, 2) express all outcomes in logs, ratios or dummies, and 3) in Table 3, we present the estimations separately by quartile of the initial value added of the plants.
} 
the timing of the reform and the the growth potential of the plants (for both exposed plants and non exposed plants separately). Whereas the identifying assumption for the triple difference is that the timing of the computerization is not correlated with what the difference in the change in the outcomes of interest (between exposed and non exposed plants) would have been in the absence of the reform. In other words there is no systematic relationship between the timing of the reform and the difference in the growth potential between exposed and non exposed plants. In section 4.3 we provide tests of whether these assumptions hold prior to the reform, using a dynamic version of our main specification, which breaks the estimation of the treatment effect by year.

Importantly, being classified as exposed or non exposed is not completely synonymous of actually being an importer or non importer during the entire study period. On average during the study period, exposed firms are $80 \%$ likely to import, whereas non exposed firms are $8 \%$ likely to import and thus to benefit from the reform. Hence the coefficients $\beta$ an underestimation of the effect of the reform on importers compared to non-importers. It can be interpreted as Intention To Treat estimation of the effect of the computerization for an importing firm (compared to a non importing firm), with a $72 \%$ compliance rate.

Finally, our analysis only keeps plants that remain in the sample from 1997 to 2008 to avoid effects due to a dropout affected by the treatment. This reduces the number of plants by half, from about 7,000 to about 3,500 . The results using the entire set of plants are qualitatively very similar. ${ }^{9}$

\subsection{Results: Effects on the Economic Activity of Manufacturing Plants}

We run the regression described in equation 1 to estimate the effect of the computerization on plant level activity. In panel A of Table 2, the effect of the interaction CustomsReform $*$ Exposure is the triple difference estimate of the reform on the change in outcome on the importing plants compared to the non-importing plants, that is, coefficient $\beta$ in the equation 1 . The second line shows the effect of CustomsReform, $\delta$, which can be interpreted as the double difference estimate of the effects of the reforms on non exposed plants. The last row of the panel presents the p-value of the sum of the two coefficients, which can also be interpreted as the double difference estimate of the effect on exposed plants. Because the standard errors are clustered at the level of the 26 customs, we also show the wild bootstrap p-value of the triple difference estimates.

Inputs is the measure that is expected to be most directly affected by the facilitation of imports. Indeed, we find that the reform led to a significant and substantial increase of inputs used by exposed firms. Interestingly, it appears that the reform significantly reduced the sales and value added of non-exposed plants by about 4 and $7 \log$ points respectively. This negative impact is consistent with the competition effect of trade in the literature, discussed previously. Additionally, we find that, in comparison to nonexposed plants, sales grew by an additional $9 \log$ points, and value added grew by an additional $13 \log$

\footnotetext{
${ }^{9}$ The results are available from the authors upon request
} 
points. When summing coefficients $\beta$ and $\delta$ for value added, we find that value added at the average exposed plant increased by a significant $6.5 \mathrm{log}$ points (p-value of 0.006). Given that the exposed firms represent $96 \%$ of the value added of the manufacturing sector, we estimate that the customs reform led to an increase of about $6 \%$ in the average manufacturing plant. We also find that the number of workers and a dummy for whether the plant is exporting both increased significantly at the average exposed plant, whereas we find no significant effect on capital. In these 3 cases, we find a negative, though statistically non-significant, effect on the non-exposed firms. Finally our indicators of productivity also show a significant increase for exposed firms resulting from the computerization of customs. Both the effect on the value added per worker and the TFP remain significant when summing coefficients $\beta$ and $\delta$. Hence our results show large effects of the computerization for the plants that are primary users of the corresponding customs posts. These effects are reflected in the scale of their economic activity as well as their productivity. However non exposed firms appeared to have suffered from the competition brought forward by the facilitation of imports.

\subsection{Parallel trends and Dynamic Effects of Computerization}

We now extend the triple-differences analysis to a dynamic specification that serves two purposes. First, it provides a check that the parallel trend hypothesis holds during the years that preceded the treatment. Second, it sheds light on the dynamic effects of the treatment, by presenting year-by year changes in the outcome variables following the implementation of the reform. The approach breaks up the estimation of the treatment effect by year:

$$
Y_{p c t}=\alpha+\sum_{y=-3}^{y=-1}\left[\beta_{y} T_{c t y} * I_{f}+\delta_{y} T_{c t y}\right]+\sum_{y=1}^{y=4}\left[\beta_{y} T_{c t y} * I_{f}+\delta_{y} T_{c t y}\right]+\lambda X_{p c t}+\theta_{p}+\gamma_{t}+\varepsilon_{p c t}
$$

where $y$ is equal to the number of years after the reform (if positive) or ( or $|y|$ year before the reform if negative) with $y=0$ on the last year before the reform, which we will refer to as the baseline year. Hence $T_{c t y}$ is a dummy equal to 1 if customs $c$ at time $t$ has used computers for exactly $y$ years if $y$ is positive. And if it is negative, $T_{c t y}$ is a dummy equal to 1 if customs $c$ at time $t$ is $|\mathrm{y}|$ years before $y=0$. The two exceptions are year $T_{c t-3}$, which we define as a dummy equal to one for any year that is three years or more prior to the baseline year for customs post $c$, and $T_{c t 4}$, which is equal to one if customs $c$ at time $t$ had been computerized for four years or more. They are included to ensure that the only omitted year is the baseline year, so that all coefficients $\beta_{y}$ can be interpreted as the triple difference effect of the year $y$ of treatment, in comparison with the baseline value. ${ }^{10}$. Hence $\beta_{y}$ is our estimation of the difference in the change in $Y_{f c t}$ between importing plants and non importing plants after $y$ years

\footnotetext{
${ }^{10}$ Our presentation of the results does not include $\beta_{y \leq-3}$ and $\beta_{y \geq 4}$ since the years for which some observations are available vary by customs depending on the year of its reform, hence their coefficients are a mix of selection and time effects, not easy to interpret and not necessary for our analysis.
} 
of computerization of the assigned custom. Also, similarly to the previous regression, $\delta_{y}$ is a measure of the change in the outcome $Y_{f c t}$ on non exposed plants that do not import after $y$ years of customs computerization (compared to a non computerized customs post). Finally $\beta_{y}+\delta_{y}$ is the equivalent for exposed plants.

Under the parallel trend assumption (for a triple difference), $\beta_{-2}$ and $\beta_{-1}$ should not differ significantly from 0 . The coefficients $\beta_{1}$ to $\beta_{3}$ are informative of how the reform affected the plants outcomes of interest over time. The effects are expected to be progressive on most economic outcomes given that 1) the customs itself should adapt to the new technology and progressively learn to make better use of the data to improve its risk profiling, and 2) Inputs from abroad should have effects through innovation and competitiveness that are likely to build up over time.

Panel B of Table 1 presents the results of estimating this dynamic specification, while Figure 3 displays the evolution of the triple-difference coefficient graphically for a few selected outcomes. Outcome variables for the exposed plants relative to the non-exposed ones are found to be relatively stable, or non significantly decreasing, in the two years preceding the reform. Of the 16 coefficients on Year of reform$2 *$ Exposure and Year of reform $-1 *$ Exposure none is significant. These results support the parallel trend hypothesis for the triple difference. Parallel trends for non-exposed plants between computerized and non-computerized custom posts also hold for 14 out of 16 coefficients (with the exception of the number of workers, which was decreasing prior to the reform). Moreover, the triple difference coefficient takes off once the reform starts, increasing progressively year after year, as anticipated. Consistent with our prior, the positive effect of the reform on the economic activity of the exposed plants grow progressively as the reform settles.

\subsection{Robustness Checks on the Economic Activity of Manufacturing Plants}

In this section, we present 3 robustness checks of the main set of results. First one may be concerned by the limited number of customs (26), and the highly uneven share of trade among customs. In particular, by itself Bogotá handles $46 \%$ of imports transactions and was the first to implement the reform. First, the results include bootstrapped standard errors by customs post to limit inference based on a small number of customs. Besides this, we present in Appendix Table 2 the eximation of model (1) when excluding, one by one, the 10 largest customs. ${ }^{11}$ The results are very consistent, indicating that the findings were not driven by any specific customs post.

Second, as described in subsection 3.2, we assigned each plant to the customs post through which imports by all firms in the plant's municipality were most likely to go, in the pre-reform period. This strategy makes the treatment binary, allowing us to examine the parallel trend assumption and dynamic effect of the treatment. However in practice, firms in the plant's municipality tend to go to multiple customs posts. Hence in Appendix Table 3, we reproduce the same strategy, but instead of matching

\footnotetext{
${ }^{11}$ In fact, for each one of the 10 largest customs separately, the estimation excludes all plants matched with that customs post
} 
each plant to the customs post with the highest importations to its municipality, we associate probabilities that are proportional to the share of imports from each customs post, in the municipality in 1999. Then the treatment variable indicates the fraction of associated port that underwent the reform. This results in a continuous treatment variable that can be interpreted as the share of imports that are expected to go through a computerized customs (based on imports of the municipality in 1999). Appendix Table 2 shows that using a continuous treatment lead to qualitatively similar conclusions with, if anything, coefficients of a larger order of magnitude, possibly because of the gain in precision.

Finally, our baseline match is based on location. By looking at customs posts most used used by each municipality, we tend to match plants with their most accessible customs post. Yet the customs posts used by a given plant are also largely determined by the type of goods imported, because it affects the country of origin and preferred type of transportation (air, sea or land). In our alternative specification, we define the treatment as the fraction of inputs of the firm that is treated, meaning that we list the inputs used by each plant, and assign to each input a level of treatment equal to the fraction of this input that goes through a treated customs post. ${ }^{12}$ The results, which we show in Appendix Table 4 remain quite similar, both in significance and magnitude of the effects, despite using this very different way of matching the plants to the customs. Similarly to the previous continuous measure of the treatment, it appears that, if anything, our baseline estimation is underestimating the effects of the customs reform. This specification and the previous one also reduce concerns about having only 26 clusters, since the treatment is continuous and not tied to a small number of clusters.

\section{Mechanisms and Additional Results}

\subsection{Firm Level Regressions on Facilitation at Customs}

This subsection analyzes the effects of the reforms on outcomes relating to import transactions, still using plant and year as the observation. By definition, these outcomes exist only for importing plants, so the comparison with non-exposed plants is no longer possible. We estimate a double-difference version of equation 1 for outcomes from the DIAN database. In particular, we estimate:

$$
Y_{p c t}=\alpha+\rho T_{c t}+\lambda X_{p c t}+\theta_{p}+\gamma_{t}+\varepsilon_{p c t}
$$

where the notation is identical to the one of equation 1 . The coefficient $\rho$ is the double-difference effect of the reform on plants at computerized ports compared to those at non-computerized ports.

Results are presented in Table 2, panel A. We find that the reform in the associated port led to

\footnotetext{
${ }^{12}$ More specifically, we first estimate, for each plant, the share of inputs corresponding to each category of good (using the HS4 codification). Second we estimate, for each category of good, the share of each customs post from which it is likely to go through. By multiplying the two across all goods that are used by a plant, we obtain the probability that imports of this plant go through each customs based on its input use in 1999. Finally, we obtain the continuous treatment variable by multiplying the probability to go through each customs by a dummy for whether the customs was treated at a given year.
} 
a reduction in the number of days to clear customs by 1.3 days (over an average of 15 days). This points towards facilitation and a reduction of bureaucracy. However the magnitude of this reduction is relatively small, and seems unlikely to explain by itself the economic changes observed in the prior section. Furthermore, the parallel trend of this variable does not hold, potentially casting doubt about the proper identification of this effect.

We also find that the ratio of all taxes collected divided by imports declared did not change significantly after the reform. Hence we can rule out positive effects of the reform through a change in tariffs. Tariffs could have increased if the computerization would make it more difficult to manipulate the categories of goods in order to pay a lower tax, however we do not find any evidence of this.

We also investigate discrepancies between taxes paid and taxes due, which according to our discussions with DIAN staff is a sign of fraud. The reform was expected to improve the communication with the bank and make sure that payment was made before releasing merchandises. The data include the amount due (after potential deductions) and the amount that was actually paid by the firm. It shows a suspicious $5 \%$ of cases where taxes due are not entirely paid (often not paid at all). We use as outcome variable the ratio between the amount paid and the tariff that is due.

As shown in column 3, this discrepancy is significantly reduced by the reform. This indicates that the reform contributed to a reduction in this form of fraud. One would expect that this would penalize the firms which, before the reform, were able to not pay the all the taxes that were due. Finally column 4 shows a significant increase in sanctions after the reform, which may reveal a switch from informal bribes to formal sanctions.

\subsection{Heterogeneous Effects by Size}

We replicate the regression of model (1), by quartile of value added in year 1999 (just before the start of the wave of reforms). This serves two purposes. First, one can be concerned that, on average importing plants are larger than non-importing plants, for example, the quartile of smallest plants is comprised of only $23 \%$ of exposed plants compared with $95 \%$ for the fourth quartile. Hence comparing plants among the ones of similar size should limit this concern. Besides this, we are also interested in learning about how different types of firms are affected.

Our findings are presented in Table 3. If we focus on the effect of value added from the first to the fourth quartile, we find an effect of $\beta+\delta$ of 4.8, 16.5, 3.7 and $2.3 \log$ points respectively. Though all estimations of the effects are positive, more significant and larger effects tend to concentrate in the second quartile. This conclusion generally holds for most outcomes (with the exception of physical capital). This heterogeneity in the effect of the reform on economic activity of the plants could be driven by two factors. First, in standard models of trade with heterogeneous production units, a given reduction in the cost of trade should lead to heterogeneous effects (Melitz, 2003; Fieler et al., 2018). It assumes fixed costs of trading, such that the most productive businesses, which in turn are the largest, already benefit from 
importing even if the cost is relatively high. Small plants have a limited ability to benefit from trade. And the medium sized plants are the ones that are most likely to extend their trade activity as a result of the cost reduction. Real-life plants are likely heterogeneous in dimensions not contemplated by this standard model, which makes it particularly telling that our findings relating scale and productivity square quite well with its basic predictions. The distribution across quartiles of the positive effect of the reform on exporting seems to also support this interpretation. Plants in the second quartile increased their likelihood by about 7.3 percentage points, which is higher than the change in other quartiles (though the difference is not significant). By contrast, those in the bottom quartile do not increase their likelihood to export even after the reform.

Second, it is possible that the cost reduction brought by the reform varies by type of firm, in particular if, before the reform, some firms only endured coercive corruption whereas others were better able to fraud or collude with customs agents. To shed light on this question, we run model (3), again splitting the sample using the same quartiles, by value added in 1999 and present the results in Appendix Table 5. ${ }^{13}$ Interestingly, the average ratio of taxes paid over due evolves around $95 \%$ to $97 \%$ for all quartiles, except the top quartile, which paid only $76 \%$ of the amount due. It is also the only group with a significant change in this variable, which increased by about 6 percentage points with the computerization. The top quartile also saw an increase in sanctions following the implementation of the reform. These patterns are consistent with the fact that large firms were more able than others to benefit from special favors, which was made more difficult by the reform. It would provide an alternative explanation why we observed in Table 3 that the top quartile is the one that benefited the least from the computerization. Under this scenario, both collusive and coercive corruption were occurring, but coercive corruption would need to be predominant for the overall effect of the reform to be positive.

\subsection{Customs Level Regressions on Activity at Customs}

In order to further understand the channels that explain our main findings, we also analyze outcomes at the customs level, still using data from the DIAN. This allows us to observe changes in total number and value going through the customs, and taxes collected.

Similarly to section 5.1 , by construction, this analysis cannot rely on relative exposure to the treatment, hence we resort to a double difference strategy, however in this subsection, each observation corresponds to a customs post and year:

$$
Y_{c t}=\alpha+\delta T_{c t}+\theta_{c}+\lambda X_{c t}+\gamma_{t}+\varepsilon_{p c t}
$$

where $\delta$ is the coefficient of interest, which tells us about the change in $Y_{c t}$ at the time of the computerization of customs $c$, and $\theta_{c}$ are customs level dummies. Standard errors are clustered at the

\footnotetext{
${ }^{13}$ Notice first that because only importing firms remain in this regression, this limits the sample, and generate a difference in the size of the samples left in each quartile, with the bottom quartiles having less observations, and thus being more noisy. Hence this set of results needs to be interpreted with caution.
} 
customs level.

We also run an accompanying dynamic specification to check the parallel trend assumption and look at the dynamics of effects. In particular, we run the following regression:

$$
Y_{c t}=\alpha+\sum_{y=-3}^{y=-1}\left[\delta_{y} T_{c t y}\right]+\sum_{y=1}^{y=4}\left[\delta_{y} T_{c t y}\right]+\theta_{c}+\lambda X_{c t}+\gamma_{t}+\varepsilon_{p c t}
$$

The definition of the treatment variables $T_{c t y}$ are analogous to those of the dynamic treatment variables in the plant-level demand specification 2. Hence, $\delta_{y}$ assesses the effect of the computerization on $Y_{c t}$ after $y$ years when $y$ is positive, and it is used to check the parallel trend when $y$ is negative. Again, the standard errors are clustered at the customs level. $X_{p c t}$ is the value of transactions in the associated customs post in 1999 interacted with year dummies, to control for changes over time that vary by initial size of customs.

The description of the intervention in section 2.2 draws our attention to many possible channels through which the reform should operate, including a reduction of smuggling, of possibilities to avoid paying due taxes, and of the customs officers' ability to impose arbitrary sanctions and additional taxes. It is also the case that the facilitation of imports could lead to an increase in imports. These port-level regressions allows us to assess these channels.

The first two columns of table $4 \mathrm{~A}$ show that the reform was followed by a drastic increase in the number of transactions (about $83 \%$ of its mean), and in the total FOB value of imports (81\%). This increase can either be due to a reduction of smuggling or to an actual increase in imports. Any of these scenarios is a sign of success for the reform, either because the registration of imports increased, or because the facilitation generated an increase in imports, or a reorientation of entry ports towards the most efficient ones. While the data available do not directly allows us to distinguish between these different channels, the combination of results that we obtain helps us to at least make some inferences about it. First, the increase in input use observed in table 2 at the plant level points towards an actual increase in imports. Interestingly, table $4 \mathrm{~B}$ shows that the effects of the reform on the number of imports and their total value also increase gradually, following the same pattern as the one observed in input use. These observations are also compatible with the progressive learning and improvements from the customs. But the increase in imports at customs appears to be of a greater order of magnitude, leaving room for other channels to be at play.

We turn our interest to taxes collected at the customs, because it is informative of the channels through which the economic activities of businesses may be affected, but also because tax collection is in itself an outcome of interest for the country (and its increase was one of the stated objectives of the reform). Column 3 shows that tax collection increased in large proportions with the reforms, by $70 \%$ of its average value, not because of an increase in the tax rate (which remained constant, as we saw in table $\mathrm{XX})$, but as a result of an increase in the tax base. However we cannot attribute all this to a country-wide 
increase in tax revenue, since it can also be due a displacement from non reformed customs to reformed ones as indicated by the following results. ${ }^{14}$

The last column of table $4 \mathrm{~A}$ shows the effect of the reform on transportation costs (from the exporting country to the customs). Total transportation costs increased by $110 \%$, hence in greater proportion than the total value of imports. Both the redirection imports and increase in transportation costs spent to reach tretaed customs are suggestive of a revealed preference for customs that underwent the computerization. This is reminescent of the findings of Sequeira and Djankov (2014) that firms in Southern Africa are willing to increase travel costs in order to go through a less corrupt port.

\subsection{Predictability of Time to Clear Customs}

We found in the plant-level analysis that the reform reduced the average time a plant's import transactions require to clear customs by about 1.3 days. However, importers care not only about the average duration to clear customs but also about its predictability. Theoretical arguments about the cost of corruption often mention the cost brought by unpredictability. Furthermore, the reform explicitely aimed to reduce the discretionary power of customs agents, which should result in more predictability for the firms going through a computerized customs. Hence in this subesction, we investigate whether an increase in the predictability of time to clear customs occured with the reform.

In Table 5, we report the $\mathrm{R} 2$ of a transaction-level regressions of time to clear customs on transaction characteristics, including weight, value and dummies for firm, product and cutoms post. The regressions include more than a million transactions. The regressions are separated by year and treatment status of the customs posts, so that it compares the R2 of treated customs to the ones of non treated customs for each year from 2001 to 2004, which are the years with a mixture of treated and non treated customs. An additional line pools together all years from 2001 to 2004 . We only included characteristics observable by the firm, so that a higher R2 can be interpreted as a greater predictability from the perspective of the firm going through the customs. Depending on the year, the R2 is significantly higher for computerized customs posts compared to the non-computerized ones of that same year, with a difference that ranges from 3.3 to 5.6 percentage points. This suggests a facilitation of imports that is reflected not only in the reduction in average time to clear customs, but also in the increased predictability for firms. This is also consistent with the reduction in the discretionary power of agents that was aimed by the reform.

\subsection{Corruption judiciary cases}

In this subsection, we add a more direct test of the hypothesis that a reduction in corruption is also part of the story. We investigate how the reform affected the number of corruption cases registered by the Procuraduría General de la Nación (the General Prosecutor) that were related to DIAN. The variables are described in Appendix Table 1D. This approach has the advantage of using a direct measure of

\footnotetext{
${ }^{14}$ In fact we calculated that total revenues collected at customs increased by about $32 \%$ from 1999 to 2008
} 
corruption, but is limited by the fact that, there are only 37 cases of corruption related to DIAN during the study period. Hence the results should be interpreted cautiously, as part of a set of evidence that point towards corruption as being one of the mechanisms at play. ${ }^{15}$

We present in Table 6 the estimation of regressions that follow the specification described in equation 4. As outcome, we use the total number of corruption cases related to DIAN (column 1) and a factor estimated by Principal Component Analysis of the 4 types of violations, to check whether the results are sensitive to the form of aggregation of the 4 types of violation (column 2). All regressions include customs and year fixed effects, as well as the total number of violations in the custom's municipality that are not related to DIAN (or the factor in column 2) . Together, this accounts for variations between customs and changes in corruption and judiciary system over time. Cases not related to DIAN has a strong predictive power of DIAN related cases and purges the estimation from determinants likely to be unrelated to the reform, assuming that it had limited spillover on corruption in the rest of the municipality. Otherwise these regressions are over-controlling and underestimating the effect (the results are robust to not including these controls). The results show a statistically significant drop in the number of irregularities reported at the DIAN, concurrent with the reform. This is consistent with a reduction in corruption being part of the channels that explains the large impact on the economic activity of manufacturing firms.

\section{Conclusion}

This paper analyzes the economic consequences for Colombian manufacturing sector of the computerization of imports declarations, accompanied by a reorganization that automatized many decisions and limited the discretionary power of customs officers. Together, the results show that a reform in the most accessible customs triggers a progressive and significant growth in the value added of the exposed firms, reaching $6 \%$ increase in the value added of these plants. This effect goes along with a growth in input use, labor, productivity and the propensity to export. These strikingly strong results goes in line with a previous literature that shows that import taxes can be quite harmful to firms productivity and growth (Trefler, 2004; Amiti and Konings, 2007; Kugler and Verhoogen, 2009; Halpern et al., 2011), and another literature showing that the "corruption tax" can have effects that are many times larger than an equivalent formal tax (Wei, 2000; Svensson, 2003). By contrast, the firms that were not importing may have been negatively affected, potentially as a consequence of their loss in competitiveness compared to importing firms. Quite strikingly, data from surveys of manufacturing firms, customs transactions and corruption cases all point towards significant improvements for importing plants when their assigned customs underwent the reform. The results are also robust to assigning customs based on the plant's

\footnotetext{
${ }^{15}$ Also an increase in the number of judiciary cases is an ambiguous indicator of corruption, since it may indicate that there is more corruption, or that corruption is more likely to be detected, hence reflect an intention by the authorities to tackle corruption. In this context, because the General Prosecutor is a national institution, we consider that, at a given period, its intention to prosecute should not vary across customs.
} 
composition of inputs rather than by proximity, lending further credence to the results.

A rich internal documentation from the DIAN goes in lengths about how the reform would tackle the flaws in the previous system that were leaving many opportunities for corruption. The qualitative insights from the documentation describe a reduction in smuggling, a better communication with transporters, banks and other stakeholders, making fraud much more difficult, and a reduction in the discretionary power of customs agents, which led to less complaints about corruption. We use it to guide our empirical approach of the channels and find a high degree of consistency of our results with the qualitative insights. The customs data on imports confirm the large increase in registered imports and tax collection, which appears to be due to a mix of a reduction in smuggling, and an a reorientation of trade flows, due to importers willing to travel longer distances to go through the automatized and less corrupt customs (similar to the results of Sequeira and Djankov, 2014). The reform reduced the manufacturing plants' time to clear customs at import by about $7 \%$ and increased the predictability of the time to clear customs from the plant's perspective. The reform was followed by a reduction in the discrepancies between the amount due by importers and the one actually paid. According to the DIAN, this was a fraud in which plants were taking advantage of the lack of communication between customs and banks. Furthermore we find that the reform was followed by a significant drop in the number of on corruption cases at the DIAN.

This paper adds to the scarce evidence on the costs of corruption at customs. It highlights the potential of new technologies to better manage information. By limiting interactions that are prone to corruption, the intervention reduced the discretionary power of the customs agents. It also allowed decisions to be based on a more rational use of the information made available by the technology. Such reforms have been promoted by international organizations, yet with little more than anecdotal evidence and qualitative studies to back the argument. This study provides new evidence of the large benefits of computerization of imports for the economy. The computerization had an estimated total cost of about nine million dollars, which is dwarfed by the estimated benefits in the form of tax collection and economic growth . Interestingly, engineers from the DIAN reported how challenging it was to obtain funding to support the development of the project. This paper provides strong evidence that when properly implemented, such investment can have a high return for the economy. The conditions that allowed this reform to be successful remain to be explained further, though in Colombia, the program was developed internally for three years prior to its first implementation. The internal documentation highlights that "it has been of singular importance for technology-process integration, that the Siglo XXI project has not been conceived exclusively by a software engineering team, but as a working group, with the inclusion between customs experts and the engineers who developed the application, in perfect collaboration with external users (customs users and unions)". We intentionally provide a fair amount of details about the content of the reform so that it can be insightful to the implementation of other customs reforms based on the automation of multiple tasks in other countries, which have not yet undergone such reform.

Rigorous evidence of successful attempts to tackle corruption remain relatively rare, in particular at 
customs level. Hence the importance to draw lessons from this case. This paper supports a growing evidence on the large benefits of proper use of information and communication technologies as a tool to improve institutions, reduce bureaucracy and tackle corruption. An interesting features that emerges from the qualitative and quantitative analysis is that a proper use of information technology implies increasing some information flows (e.g. to increase accountability), but also intentionally cutting some information links (when the risk of coercion or collusion is high). We see a better understanding of such feature in order to make the most of information technologies that were not available a few years ago as a promising area for research, institutional development and economic development. 


\section{References}

Amiti, Mary and Jozef Konings, "Trade liberalization, intermediate inputs, and productivity: Evidence from Indonesia," The American Economic Review, 2007, 97 (5), 1611-1638.

Banerjee, Abhijit, Esther Duflo, Clement Imbert, Santhosh Mathew, and Rohini Pande, "E-governance, accountability, and leakage in public programs: Experimental evidence from a financial management reform in india," Technical Report, National Bureau of Economic Research 2016.

Batra, Geeta, Daniel Kaufmann, and Andrew HW Stone, "The firms speak: What the world business environment survey tells us about constraints on private sector development," in "Pathways Out of Poverty," Springer, 2003, pp. 193-214.

Cameron, A Colin, Jonah B Gelbach, and Douglas L Miller, "Bootstrap-based improvements for inference with clustered errors," The Review of Economics and Statistics, 2008, 90 (3), 414-427.

Clark, Ximena, David Dollar, and Alejandro Micco, "Port efficiency, maritime transport costs, and bilateral trade," Journal of development economics, 2004, 75 (2), 417-450.

Dollar, David, Mary Hallward-Driemeier, and Taye Mengistae, "Investment Climate, Infrastructure and Trade: A Comparison of Latin America and Asia," World Bank. Washington, DC Processed, 2003.

Ebeke, Christian, Luc Désiré Omgba, and Rachid Laajaj, "Oil, governance and the (mis) allocation of talent in developing countries," Journal of Development Economics, 2015, 114, 126-141.

Engman, Michael, "The economic impact of trade facilitation," 2005.

Eslava, Marcela, Ana Cecília Fieler, and Daniel Yi Xu, "(Indirect) Input Linkages," American Economic Review, 2015, 105 (5), 662-66.

Ferraz, Claudio, Frederico Finan, and Diana B Moreira, "Corrupting learning: Evidence from missing federal education funds in Brazil," Journal of Public Economics, 2012, 96 (9), 712-726.

Fieler, Ana Cecília, Marcela Eslava, and Daniel Yi Xu, "Trade, Quality Upgrading, and Input Linkages: Theory and Evidence from Colombia," American Economic Review, 2018, 108 (1), 109-46.

Giné, Xavier, Jessica Goldberg, and Dean Yang, "Credit market consequences of improved personal identification: Field experimental evidence from Malawi," The American Economic Review, 2012, 102 (6), 2923-2954.

Guasch, J Luis and Joseph Kogan, Inventories in Developing Countries: Levels and Determinants: A Red Flag for Competitiveness and Growth, Vol. 2552, World Bank Publications, 2001. 
Halpern, László, Miklós Koren, Adam Szeidl et al., "Imported inputs and productivity," American Economic Review, REBR, 2011, 2 (3), 9.

Khwaja, Asim Ijaz and Atif Mian, "Do lenders favor politically connected firms? Rent provision in an emerging financial market," The Quarterly Journal of Economics, 2005, 120 (4), 1371-1411.

Kugler, Maurice and Eric Verhoogen, "Plants and imported inputs: New facts and an interpretation," The American Economic Review, 2009, 99 (2), 501-507.

Lewis-Faupel, Sean, Yusuf Neggers, Benjamin A Olken, and Rohini Pande, "Can Electronic Procurement Improve Infrastructure Provision? Evidence from Public Works in India and Indonesia," American Economic Journal: Economic Policy, 2016, 8 (3), 258-83.

Mauro, Paolo, "Corruption and growth," The quarterly journal of economics, 1995, 110 (3), 681-712.

Melitz, Marc J, "The impact of trade on intra-industry reallocations and aggregate industry productivity," Econometrica, 2003, 71 (6), 1695-1725.

Muralidharan, Karthik, Paul Niehaus, and Sandip Sukhtankar, "Building state capacity: Evidence from biometric smartcards in India," American Economic Review, 2016, 106 (10), 2895-2929.

Olken, Benjamin A, "Corruption and the costs of redistribution: Micro evidence from Indonesia," Journal of public economics, 2006, 90 (4), 853-870.

- and Patrick Barron, "The simple economics of extortion: evidence from trucking in Aceh," Journal of Political Economy, 2009, 117 (3), 417-452.

- and Rohini Pande, "Corruption in developing countries," Annu. Rev. Econ., 2012, 4 (1), 479-509.

Porta, Rafael La, Florencio Lopez de Silanes, Andrei Shleifer, and Robert Vishny, "The quality of government," The Journal of Law, Economics, and Organization, 1999, 15 (1), 222-279.

${ }_{-},{ }_{-},{ }_{-}$and $\ldots$, "Investor protection and corporate governance," Journal of financial economics, 2000, $58(1), 3-27$.

Reinikka, Ritva and Jakob Svensson, "Local capture: evidence from a central government transfer program in Uganda," The Quarterly Journal of Economics, 2004, 119 (2), 679-705.

Rodrik, Dani, Arvind Subramanian, and Francesco Trebbi, "Institutions rule: the primacy of institutions over geography and integration in economic development," Journal of economic growth, 2004, 9 (2), 131-165.

Sachs, Jeffrey D, Andrew Warner, Anders Åslund, and Stanley Fischer, "Economic reform and the process of global integration," Brookings papers on economic activity, 1995, 1995 (1), 1-118. 
Samphantharak, Krislert and Edmund J Malesky, "Predictable corruption and firm investment: evidence from a natural experiment and survey of Cambodian entrepreneurs," 2008.

Sequeira, Sandra, Corruption and Trade Costs, Edward Elgar, 2015.

_ , "Corruption, trade costs, and gains from tariff liberalization: evidence from Southern Africa," American Economic Review, 2016, 106 (10), 3029-63.

- and Simeon Djankov, "Corruption and firm behavior: Evidence from African ports," Journal of International Economics, 2014, 94 (2), 277-294.

Svensson, Jakob, "Who Must Pay Bribes and How Much? Evidence from a Cross Section of Firms," The Quarterly Journal of Economics, 2003, 118 (1), 207-230.

Trefler, Daniel, "The long and short of the Canada-US free trade agreement," The American Economic Review, 2004, 94 (4), 870-895.

Wacziarg, Romain and Karen Horn Welch, "Trade liberalization and growth: New evidence," The World Bank Economic Review, 2008, 22 (2), 187-231.

Wei, Shang-Jin, "How taxing is corruption on international investors?," Review of economics and statistics, 2000, 82 (1), 1-11.

Wulf, Luc De and José B Sokol, Customs Modernization Initiatives: Case Studies, World Bank Publications, 2004.

Yang, Dean, "18 The economics of anti-corruption: lessons from a widespread customs reform," International handbook on the economics of corruption, 2006, p. 512. 
Figure 1: Proportion of imports in Colombia declared by Computer

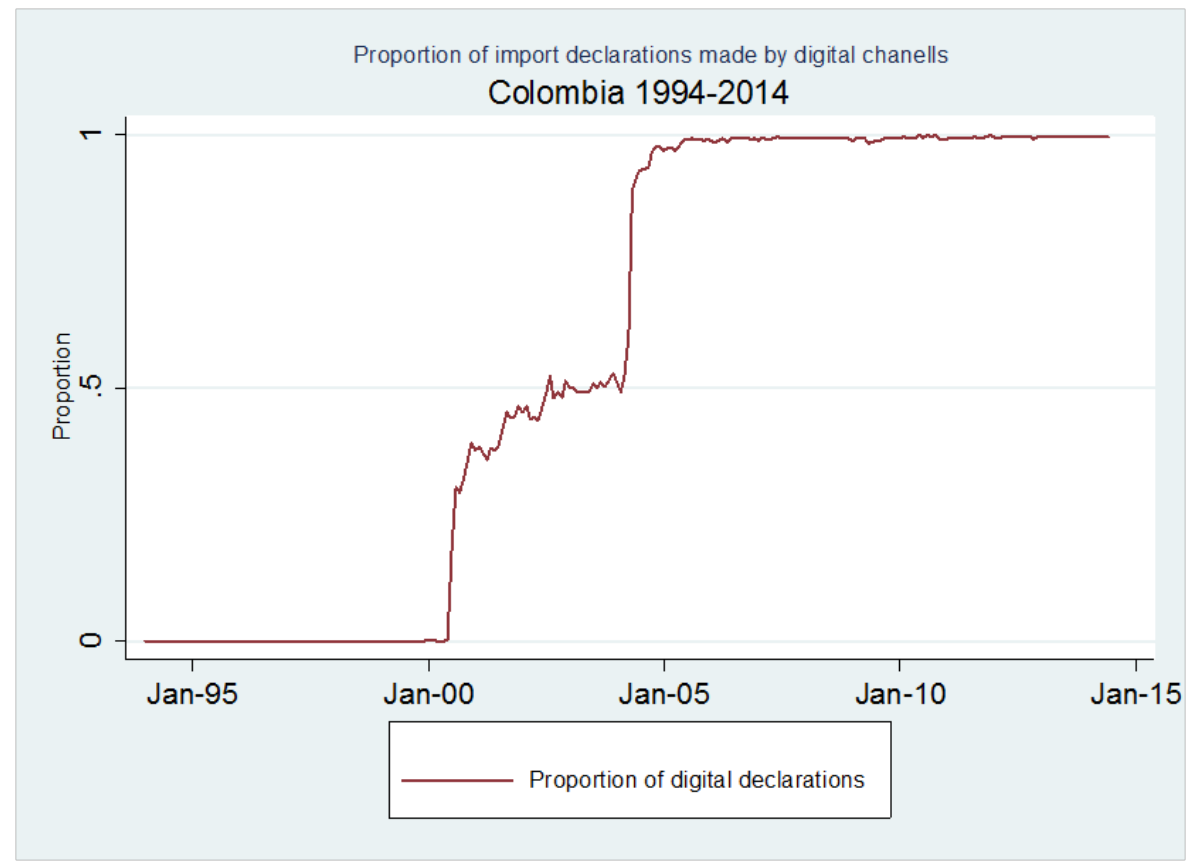

Figure 1 presents the proportion of import transactions in Colombia that were declared by computer. Using data from the DIAN from 1994 to 2014, we calculated by month, the average across all transactions of a dummy equal to one if the transaction was declared by computer. 
Figure 2 Proportion of imports Declared by Computer in 15 Largest Customs
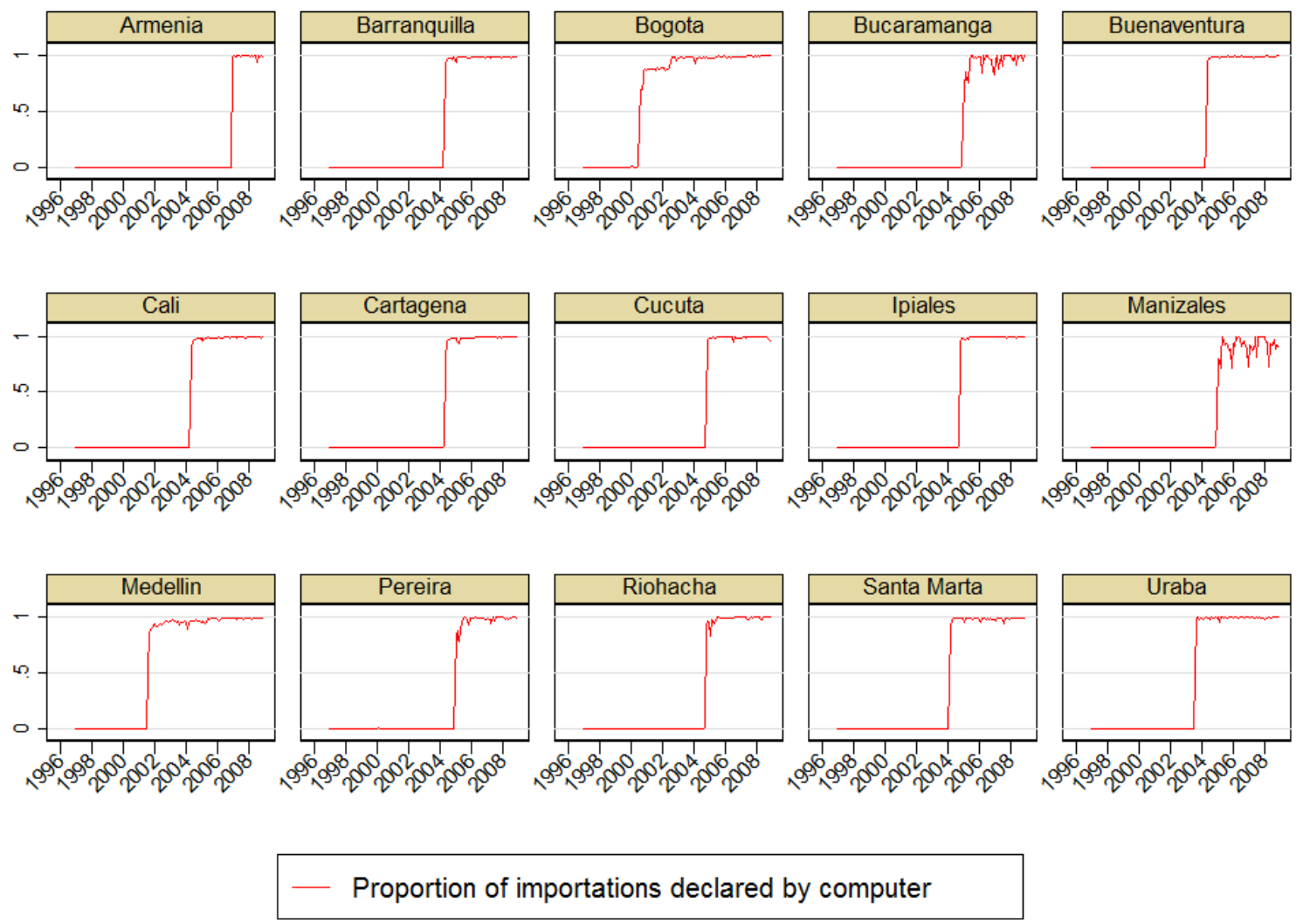

Figure 2 presents the proportion of imports declared by computer for each one of the 15 largest custom posts. Using data from the DIAN from 1994 to 2014, we calculated by month the average across all transactions of each customs post of a dummy equal to one if the transaction was declared by computer. 
Figure 3: Dynamic triple difference effect of the customs reform on key outcomes

Yearly Treatment Effects on Material Inputs (log)

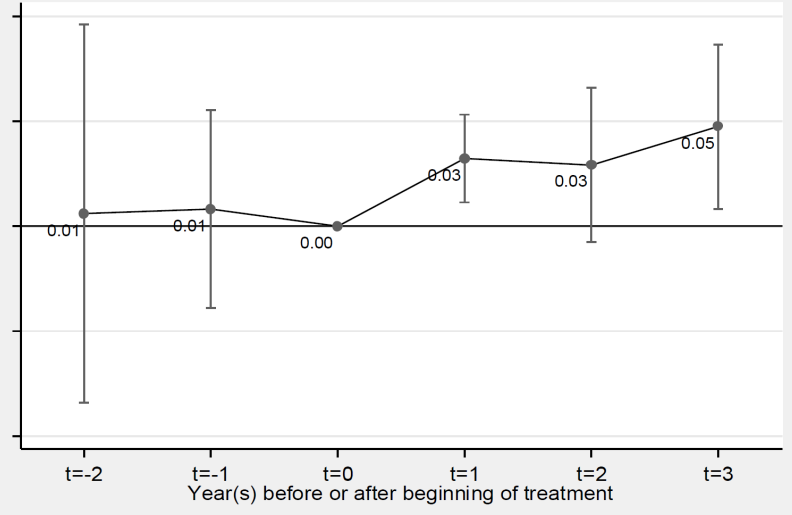

Yearly Treatment Effects on Sales (log)

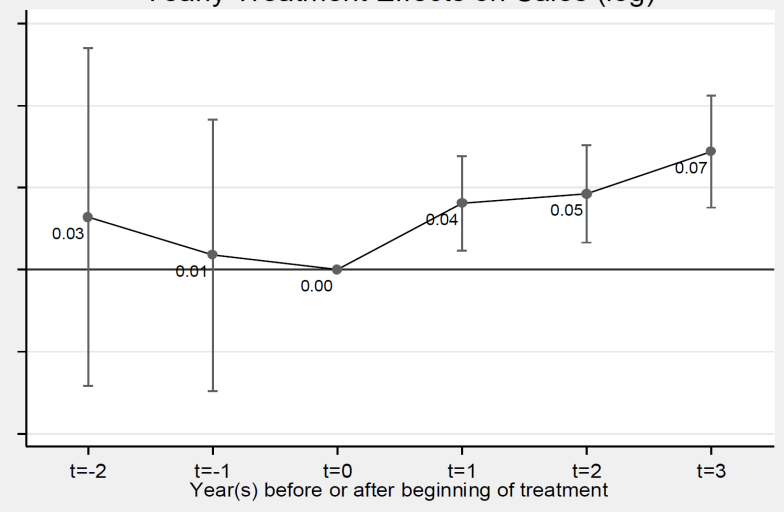

Yearly Treatment Effects on Value Added per Worker (log)

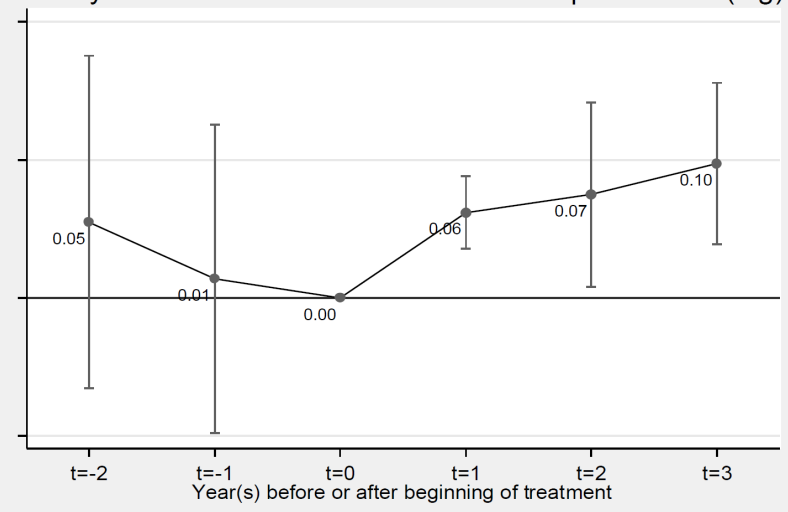

Yearly Treatment Effects on Value Added (log)

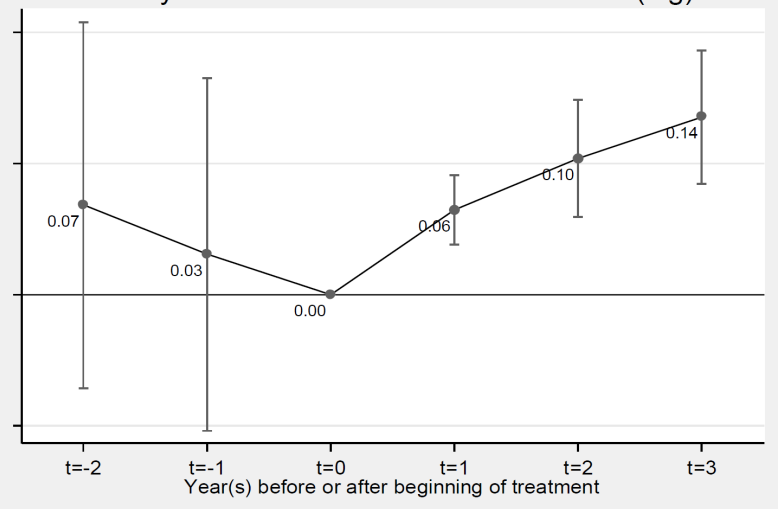

Yearly Treatment Effects on Number of Workers (log)

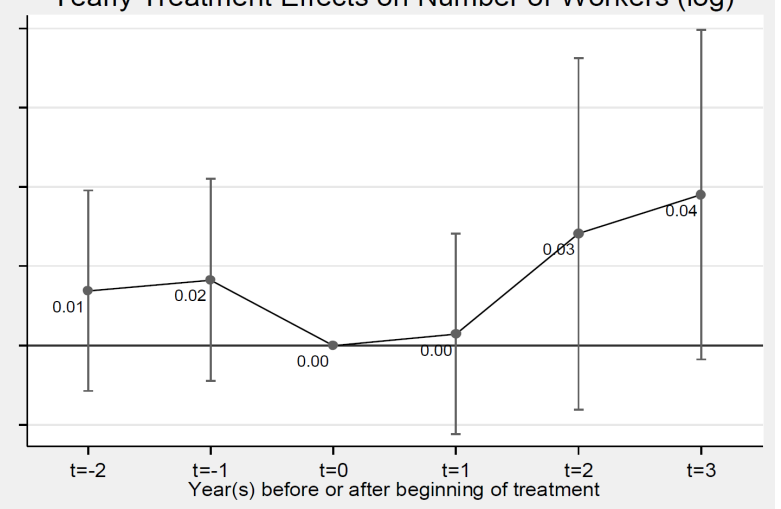

Yearly Treatment Effects on TFP

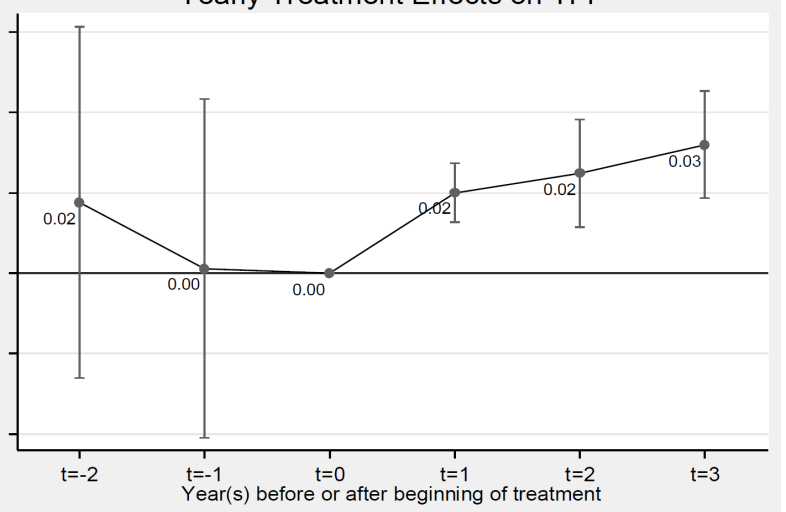

Figure 3 provides a visual representation of the triple difference effects of changes at plant level before and after the reform, corresponding to model (2) and presented in Table 1B. 
Table 1A: Triple Difference Estimation of the Effects of the Reform on the Activity of Manufacturing Plants

\begin{tabular}{|c|c|c|c|c|c|c|c|c|}
\hline VARIABLES & Log Inputs & Log Sales & $\begin{array}{l}\text { Log Value } \\
\text { Added }\end{array}$ & $\begin{array}{l}\text { Log Number } \\
\text { of workers }\end{array}$ & Log Capital & $\begin{array}{l}\text { Export } \\
\text { dummy }\end{array}$ & $\begin{array}{c}\text { Log Value } \\
\text { Added per } \\
\text { Worker } \\
\end{array}$ & TFP \\
\hline Exposure * Customs Reform & $\begin{array}{c}0.067^{* * * *} \\
(0.018)\end{array}$ & $\begin{array}{c}0.088^{* * * *} \\
(0.024)\end{array}$ & $\begin{array}{c}0.133^{* * * *} \\
(0.027)\end{array}$ & $\begin{array}{c}0.059^{* * * *} \\
(0.018)\end{array}$ & $\begin{array}{c}0.033 \\
(0.024)\end{array}$ & $\begin{array}{l}0.084 * * \\
(0.034)\end{array}$ & $\begin{array}{c}0.074 * * * * \\
(0.016)\end{array}$ & $\begin{array}{l}0.025 * * \\
(0.0094)\end{array}$ \\
\hline Customs Reform & $\begin{array}{l}-0.009 \\
(0.018)\end{array}$ & $\begin{array}{c}-0.038^{* * *} \\
(0.015)\end{array}$ & $\begin{array}{c}-0.068 * * * \\
(0.016)\end{array}$ & $\begin{array}{c}-0.02 \\
(0.014)\end{array}$ & $\begin{array}{l}-0.038 \\
(0.021)\end{array}$ & $\begin{array}{l}-0.036 \\
(0.029)\end{array}$ & $\begin{array}{c}-0.048 * * \\
(0.015)\end{array}$ & $\begin{array}{c}-0.012 \\
(0.0067)\end{array}$ \\
\hline $\begin{array}{l}\text { Observations } \\
\text { Wild Bootstrap p-value } \\
\text { p-val of sum of both coef. }\end{array}$ & $\begin{array}{c}41,556 \\
0.015 \\
0.003 \\
\end{array}$ & $\begin{array}{c}41,556 \\
0.031 \\
0.001 \\
\end{array}$ & $\begin{array}{c}41,494 \\
0.031 \\
0.006 \\
\end{array}$ & $\begin{array}{c}41,556 \\
0.03 \\
0.000 \\
\end{array}$ & $\begin{array}{c}41,556 \\
0.046 \\
0.766 \\
\end{array}$ & $\begin{array}{c}41,556 \\
0.003 \\
0.066 \\
\end{array}$ & $\begin{array}{c}41,494 \\
0.012 \\
0.070 \\
\end{array}$ & $\begin{array}{c}41,556 \\
0.005 \\
0.058 \\
\end{array}$ \\
\hline VARIABLES & Log Inputs & Log Sales & $\begin{array}{l}\text { Log Value } \\
\text { Added }\end{array}$ & $\begin{array}{l}\text { Log Number } \\
\text { of workers }\end{array}$ & Log Capital & $\begin{array}{l}\text { Export } \\
\text { dummy }\end{array}$ & $\begin{array}{c}\text { Log Value } \\
\text { Added per } \\
\text { Worker } \\
\end{array}$ & TFP \\
\hline Exposure $* 2$ years before treat. & $\begin{array}{c}0.006 \\
(0.040)\end{array}$ & $\begin{array}{c}0.032 \\
(0.045)\end{array}$ & $\begin{array}{c}0.068 \\
(0.062)\end{array}$ & $\begin{array}{c}0.014 \\
(0.011)\end{array}$ & $\begin{array}{c}-0.004 \\
(0.0071)\end{array}$ & $\begin{array}{c}-0.044 \\
(0.037)\end{array}$ & $\begin{array}{c}0.055 \\
(0.053)\end{array}$ & $\begin{array}{c}0.018 \\
(0.019)\end{array}$ \\
\hline Exposure $* 1$ year before treat. & $\begin{array}{c}0.008 \\
(0.021)\end{array}$ & $\begin{array}{c}0.009 \\
(0.037)\end{array}$ & $\begin{array}{c}0.031 \\
(0.060)\end{array}$ & $\begin{array}{c}0.017 \\
(0.011)\end{array}$ & $\begin{array}{c}0.009 \\
(0.012)\end{array}$ & $\begin{array}{c}-0.038 \\
(0.034)\end{array}$ & $\begin{array}{c}0.014 \\
(0.049)\end{array}$ & $\begin{array}{c}0.001 \\
(0.019)\end{array}$ \\
\hline Exposure * 1 year after treat. & $\begin{array}{l}0.032 * * * \\
(0.0093)\end{array}$ & $\begin{array}{l}0.04 * * \\
(0.013)\end{array}$ & $\begin{array}{c}0.065^{* * * *} \\
(0.012)\end{array}$ & $\begin{array}{c}0.003 \\
(0.011)\end{array}$ & $\begin{array}{c}0.009 \\
(0.012)\end{array}$ & $\begin{array}{c}0.063 \\
(0.067)\end{array}$ & $\begin{array}{c}0.062 * * * * \\
(0.012)\end{array}$ & $\begin{array}{l}0.02 * * * \\
(0.0033)\end{array}$ \\
\hline Exposure $* 2$ years after treat. & $\begin{array}{c}0.029 \\
(0.016)\end{array}$ & $\begin{array}{c}0.046^{* * *} \\
(0.013)\end{array}$ & $\begin{array}{c}0.104 * * * \\
(0.020)\end{array}$ & $\begin{array}{c}0.028 \\
(0.020)\end{array}$ & $\begin{array}{c}0.019 \\
(0.015)\end{array}$ & $\begin{array}{c}0.049 \\
(0.065)\end{array}$ & $\begin{array}{c}0.075^{* *} \\
(0.030)\end{array}$ & $\begin{array}{c}0.025 * * * \\
(0.0059)\end{array}$ \\
\hline Exposure $* 3$ years after treat. & $\begin{array}{c}0.047 * * \\
(0.017)\end{array}$ & $\begin{array}{c}0.072 * * * * \\
(0.015)\end{array}$ & $\begin{array}{c}0.136 * * * \\
(0.022)\end{array}$ & $\begin{array}{l}0.038^{*} \\
(0.018)\end{array}$ & $\begin{array}{c}0.016 \\
(0.022)\end{array}$ & $\begin{array}{c}0.046 \\
(0.059)\end{array}$ & $\begin{array}{c}0.097^{* * * *} \\
(0.026)\end{array}$ & $\begin{array}{c}0.032 * * * \\
(0.0059)\end{array}$ \\
\hline 2 years before treatment & $\begin{array}{c}-0.04 \\
(0.045)\end{array}$ & $\begin{array}{l}-0.056 \\
(0.039)\end{array}$ & $\begin{array}{l}-0.059 \\
(0.047)\end{array}$ & $\begin{array}{c}-0.027^{* * *} \\
(0.011)\end{array}$ & $\begin{array}{c}0.008 \\
(0.0092)\end{array}$ & $\begin{array}{c}0.01 \\
(0.024)\end{array}$ & $\begin{array}{l}-0.033 \\
(0.041)\end{array}$ & $\begin{array}{l}-0.014 \\
(0.014)\end{array}$ \\
\hline 1 year before treatment & $\begin{array}{l}-0.029 \\
(0.025)\end{array}$ & $\begin{array}{l}-0.027 \\
(0.025)\end{array}$ & $\begin{array}{l}-0.033 \\
(0.036)\end{array}$ & $\begin{array}{l}-0.017^{*} \\
(0.0087)\end{array}$ & $\begin{array}{c}-0.001 \\
(0.0094)\end{array}$ & $\begin{array}{l}-0.001 \\
(0.021)\end{array}$ & $\begin{array}{l}-0.016 \\
(0.029)\end{array}$ & $\begin{array}{l}-0.008 \\
(0.011)\end{array}$ \\
\hline 1 year after treatment & $\begin{array}{c}0.001 \\
(0.022)\end{array}$ & $\begin{array}{c}-0.034 * * \\
(0.013)\end{array}$ & $\begin{array}{c}-0.053^{* * * *} \\
(0.011)\end{array}$ & $\begin{array}{l}-0.007 \\
(0.010)\end{array}$ & $\begin{array}{l}-0.038^{*} \\
(0.020)\end{array}$ & $\begin{array}{c}-0.023 \\
(0.042)\end{array}$ & $\begin{array}{c}-0.046^{* * * *} \\
(0.012)\end{array}$ & $\begin{array}{c}-0.015^{* *} \\
(0.0065)\end{array}$ \\
\hline 2 years after treatment & $\begin{array}{l}-0.001 \\
(0.025)\end{array}$ & $\begin{array}{c}-0.037 * * \\
(0.013)\end{array}$ & $\begin{array}{c}-0.073^{* * * *} \\
(0.014)\end{array}$ & $\begin{array}{l}-0.008 \\
(0.017)\end{array}$ & $\begin{array}{c}-0.053^{*} \\
(0.026)\end{array}$ & $\begin{array}{l}-0.013 \\
(0.040)\end{array}$ & $\begin{array}{c}-0.066^{* * *} \\
(0.022)\end{array}$ & $\begin{array}{c}-0.018 \\
(0.0098)\end{array}$ \\
\hline 3 years after treatment & $\begin{array}{c}0.023 \\
(0.027)\end{array}$ & $\begin{array}{l}-0.017 \\
(0.018)\end{array}$ & $\begin{array}{l}-0.056^{*} \\
(0.026)\end{array}$ & $\begin{array}{l}-0.007 \\
(0.017)\end{array}$ & $\begin{array}{l}-0.059^{*} \\
(0.029)\end{array}$ & $\begin{array}{c}0.007 \\
(0.038)\end{array}$ & $\begin{array}{l}-0.05^{*} \\
(0.025)\end{array}$ & $\begin{array}{l}-0.002 \\
(0.011)\end{array}$ \\
\hline
\end{tabular}


Table 2A: Double Difference Estimation of the Effects of the Reform on Imports Caracteristics using Customs Information (observations at firm year level)

\begin{tabular}{|c|c|c|c|c|}
\hline VARIABLES & $\begin{array}{c}\text { Custom } \\
\text { Clearence Time }\end{array}$ & $\begin{array}{c}\text { Paid/FOB } \\
\text { Import Value }\end{array}$ & Paid/Due & $\begin{array}{l}\text { Sanctions/FOB } \\
\text { import value }\end{array}$ \\
\hline Customs Reform & $\begin{array}{l}-1.27 * * * \\
(0.28)\end{array}$ & $\begin{array}{l}-0.001 \\
(0.0070)\end{array}$ & $\begin{array}{l}0.052 * * \\
(0.019)\end{array}$ & $\begin{array}{c}0.0005 * * \\
(0.000018)\end{array}$ \\
\hline Observations & 19,214 & 19,272 & 18,987 & 19,272 \\
\hline Wild Bootstrap p-value ${ }^{1}$ & 0.731 & 0.87 & 0.116 & 0.186 \\
\hline Mean of outcome var. & 15 & 0.031 & 0.86 & 0.000036 \\
\hline \multicolumn{5}{|c|}{$\begin{array}{l}\text { Table 2B: Year by Year Estimation of the Effects of the Reform on Imports Caracteristics using } \\
\text { Customs Information (observations at firm year level) }\end{array}$} \\
\hline VARIABLES & $\begin{array}{c}\text { Custom } \\
\text { Clearence Time }\end{array}$ & Paid/FOB & Paid/Due & $\begin{array}{l}\text { Sanctions/FOB } \\
\text { import value }\end{array}$ \\
\hline 2 years before treatment & $\begin{array}{c}1.841 * * * \\
(0.41)\end{array}$ & $\begin{array}{c}0.004 \\
(0.024)\end{array}$ & $\begin{array}{l}-0.067 * \\
(0.033)\end{array}$ & $\begin{array}{c}0.00003 \\
(0.000030)\end{array}$ \\
\hline 1 year before treatment & $\begin{array}{c}2.776 * * * \\
(0.64)\end{array}$ & $\begin{array}{l}-0.0003 \\
(0.022)\end{array}$ & $\begin{array}{l}-0.017 \\
(0.038)\end{array}$ & $\begin{array}{c}0.000003 \\
(0.000024)\end{array}$ \\
\hline 1 year after treatment & $\begin{array}{l}-0.243 \\
(0.38)\end{array}$ & $\begin{array}{c}0.001 \\
(0.017)\end{array}$ & $\begin{array}{c}0.058 * * \\
(0.025)\end{array}$ & $\begin{array}{c}0.00009 * \\
(0.000043)\end{array}$ \\
\hline 2 years after treatment & $\begin{array}{c}0.980 * * * \\
(0.30)\end{array}$ & $\begin{array}{c}-0.009 \\
(0.0095)\end{array}$ & $\begin{array}{l}0.115 * * \\
(0.050)\end{array}$ & $\begin{array}{c}0.00007 \\
(0.000048)\end{array}$ \\
\hline 3 years after treatment & $\begin{array}{l}-0.165 \\
(0.16)\end{array}$ & $\begin{array}{c}-0.009 \\
(0.0068)\end{array}$ & $\begin{array}{c}0.119 * * * \\
(0.013)\end{array}$ & $\begin{array}{l}0.00009 * * \\
(0.000035)\end{array}$ \\
\hline
\end{tabular}

Table 2A reports estimation results from estimating model (3) and 2B reports estimation of the same model separating treatement effects by year. Each observation corresponds to a firm and year. It includes all (the 1,837) manufacturing firms in Colombia that could be matched to the customs data, and available from 1997 to 2008. "Customs Reform" is a treatment dummy equal to 1 starting the first year when more than $80 \%$ of import transactions were computerized in the customs associated to the plant. Controls include plant and year Fixed Effects, initial $\log$ of value added of the plant interacted with year dummies and initial $\log$ of size of the customs interacted with year dummies. Observations are weighted by the value added of the firm in 1999, before any reform started. Standard errors clustered at customs level are in parenthesis. *** $\mathrm{p}<0.01$, $* * \mathrm{p}<0.05, * \mathrm{p}<0.1$. 
Table 3: Effect of computerization on firms economic activity, separating firms by quartile of value added in 1999

\begin{tabular}{|c|c|c|c|c|c|c|c|c|c|}
\hline $\begin{array}{l}\text { Quartile (of } \\
\text { VA in 1999) }\end{array}$ & VARIABLES (in log): & Inputs & Sales & $\begin{array}{l}\text { Value } \\
\text { Added }\end{array}$ & $\begin{array}{c}\text { Number of } \\
\text { workers }\end{array}$ & Capital & $\begin{array}{c}\text { Value } \\
\text { Added per } \\
\text { Worker } \\
\end{array}$ & $\begin{array}{l}\text { Export } \\
\text { dummy }\end{array}$ & TFP \\
\hline \multirow{2}{*}{$\begin{array}{c}\text { Quartile 1 } \\
\text { (Exposure = } \\
\mathbf{2 3 \%})\end{array}$} & $\begin{array}{l}\text { Customs Reform * } \\
\text { Exposure }\end{array}$ & $\begin{array}{c}0.019 \\
(0.054)\end{array}$ & $\begin{array}{c}0.056 \\
(0.073)\end{array}$ & $\begin{array}{c}0.133 \\
(0.076)\end{array}$ & $\begin{array}{l}0.068^{*} \\
(0.033)\end{array}$ & $\begin{array}{l}0.08 * * \\
(0.026)\end{array}$ & $\begin{array}{c}0.064 \\
(0.053)\end{array}$ & $\begin{array}{l}0.062 * * \\
(0.026)\end{array}$ & $\begin{array}{c}0.026 \\
(0.029)\end{array}$ \\
\hline & Customs Reform & $\begin{array}{c}0.034 \\
(0.026)\end{array}$ & $\begin{array}{l}-0.029 \\
(0.025)\end{array}$ & $\begin{array}{c}-0.085^{* *} \\
(0.030)\end{array}$ & $\begin{array}{c}0.001 \\
(0.0092)\end{array}$ & $\begin{array}{l}-0.059^{*} \\
(0.028)\end{array}$ & $\begin{array}{c}-0.085^{* * * *} \\
(0.023)\end{array}$ & $\begin{array}{l}-0.026^{*} \\
(0.013)\end{array}$ & $\begin{array}{l}-0.03^{*} \\
(0.015)\end{array}$ \\
\hline \multirow{2}{*}{$\begin{array}{c}\text { Quartile 2 } \\
\text { (Exposure = } \\
\mathbf{4 3 \%} \text { ) }\end{array}$} & $\begin{array}{l}\text { Customs Reform * } \\
\text { Exposure }\end{array}$ & $\begin{array}{l}0.085^{* *} \\
(0.036)\end{array}$ & $\begin{array}{c}0.127^{* * * *} \\
(0.032)\end{array}$ & $\begin{array}{c}0.193^{* * * *} \\
(0.042)\end{array}$ & $\begin{array}{l}0.08^{* * *} \\
(0.029)\end{array}$ & $\begin{array}{l}-0.015 \\
(0.040)\end{array}$ & $\begin{array}{l}0.112 * * \\
(0.043)\end{array}$ & $\begin{array}{l}0.092 * \\
(0.044)\end{array}$ & $\begin{array}{l}0.042^{* *} \\
(0.013)\end{array}$ \\
\hline & Customs Reform & $\begin{array}{l}-0.026 \\
(0.018)\end{array}$ & $\begin{array}{c}-0.039 * * \\
(0.017)\end{array}$ & $\begin{array}{l}-0.028 \\
(0.022)\end{array}$ & $\begin{array}{l}-0.0001 \\
(0.039)\end{array}$ & $\begin{array}{c}0.006 \\
(0.046)\end{array}$ & $\begin{array}{l}-0.028 \\
(0.028)\end{array}$ & $\begin{array}{l}-0.019 \\
(0.026)\end{array}$ & $\begin{array}{c}-0.001 \\
(0.0098)\end{array}$ \\
\hline \multirow{2}{*}{$\begin{array}{c}\text { Quartile 3 } \\
\text { (Exposure = } \\
76 \%)\end{array}$} & $\begin{array}{l}\text { Customs Reform * } \\
\text { Exposure }\end{array}$ & $\begin{array}{l}0.072 * \\
(0.038)\end{array}$ & $\begin{array}{l}0.088 * * \\
(0.035)\end{array}$ & $\begin{array}{l}0.113^{* *} \\
(0.039)\end{array}$ & $\begin{array}{c}0.04 \\
(0.031)\end{array}$ & $\begin{array}{c}0.029 \\
(0.039)\end{array}$ & $\begin{array}{l}0.074^{* *} \\
(0.029)\end{array}$ & $\begin{array}{l}0.088^{*} \\
(0.040)\end{array}$ & $\begin{array}{l}0.028^{*} \\
(0.014)\end{array}$ \\
\hline & Customs Reform & $\begin{array}{l}-0.019 \\
(0.042)\end{array}$ & $\begin{array}{l}-0.045 \\
(0.044)\end{array}$ & $\begin{array}{l}-0.076 \\
(0.055)\end{array}$ & $\begin{array}{l}-0.018 \\
(0.038)\end{array}$ & $\begin{array}{l}-0.021 \\
(0.043)\end{array}$ & $\begin{array}{l}-0.058 \\
(0.038)\end{array}$ & $\begin{array}{l}-0.046 \\
(0.046)\end{array}$ & $\begin{array}{l}-0.021 \\
(0.015)\end{array}$ \\
\hline \multirow{2}{*}{$\begin{array}{c}\text { Quartile 4 } \\
\text { (Exposure = } \\
95 \%)\end{array}$} & $\begin{array}{l}\text { Customs Reform * } \\
\text { Exposure }\end{array}$ & $\begin{array}{c}0.049 \\
(0.066)\end{array}$ & $\begin{array}{l}-0.016 \\
(0.044)\end{array}$ & $\begin{array}{l}-0.058 \\
(0.042)\end{array}$ & $\begin{array}{l}-0.139 \\
(0.095)\end{array}$ & $\begin{array}{l}-0.181 * \\
(0.086)\end{array}$ & $\begin{array}{c}0.08 \\
(0.11)\end{array}$ & $\begin{array}{c}0.182 * * * \\
(0.049)\end{array}$ & $\begin{array}{l}0.016 \\
(0.017)\end{array}$ \\
\hline & Customs Reform & $\begin{array}{c}-0.01 \\
(0.064)\end{array}$ & $\begin{array}{c}0.046 \\
(0.042)\end{array}$ & $\begin{array}{l}0.081^{*} \\
(0.039)\end{array}$ & $\begin{array}{c}0.128 \\
(0.095)\end{array}$ & $\begin{array}{l}0.154^{*} \\
(0.082)\end{array}$ & $\begin{array}{l}-0.046 \\
(0.099)\end{array}$ & $\begin{array}{c}-0.165 * * \\
(0.058)\end{array}$ & $\begin{array}{c}0.003 \\
(0.013)\end{array}$ \\
\hline
\end{tabular}


Table 4A: Double Difference Estimation of the Effects of the Reform on Imports Caracteristics using Customs Information (observations at customs year level)

\begin{tabular}{|c|c|c|c|c|}
\hline VARIABLES & $\begin{array}{c}\mathrm{Nb} \text { of } \\
\text { importations }\end{array}$ & $\begin{array}{l}\text { Total value of } \\
\text { imports (FOB) }\end{array}$ & $\begin{array}{c}\text { Total Taxes } \\
\text { (VAT }+ \\
\text { Tariff) }\end{array}$ & $\begin{array}{c}\text { Transportation } \\
\text { Costs }\end{array}$ \\
\hline Custom Reform & $\begin{array}{l}37,647 * * \\
(14,828)\end{array}$ & $\begin{array}{c}1,042 * * \\
(432)\end{array}$ & $\begin{array}{l}23.7 * * \\
(10.9)\end{array}$ & $\begin{array}{l}11.0 * * \\
(5.14)\end{array}$ \\
\hline Observations & 312 & 312 & 312 & 312 \\
\hline Wild Bootstrap p-value ${ }^{1}$ & .0072 & .0088 & .0068 & .0048 \\
\hline Mean of outcome var. & 45,510 & 1,230 & 30.6 & 9.27 \\
\hline
\end{tabular}

Table 4B: Year by Year Estimation of the Effects of the Reform on Imports Caracteristics using Customs Information (observations at customs year level)

\begin{tabular}{lcccc}
\hline VARIABLES & $\begin{array}{c}\text { Nb of } \\
\text { importations }\end{array}$ & $\begin{array}{c}\text { Total value of } \\
\text { imports (FOB) }\end{array}$ & $\begin{array}{c}\text { Total Taxes } \\
\text { (VAT }+ \\
\text { Tariff) }\end{array}$ & $\begin{array}{c}\text { Transportation } \\
\text { Costs }\end{array}$ \\
\hline 2 years before treatment & $-6,868$ & -178.2 & -4.096 & -3.996 \\
& $(10,387)$ & $(268.5)$ & $(5.669)$ & $(3.158)$ \\
1 year before treatment & $-8,525$ & -208.7 & -3.602 & -9.115 \\
& $(7,134)$ & $(142.2)$ & $(2.687)$ & $(5.782)$ \\
1 year after treatment & 3,151 & 91.91 & 2.289 & $2.475^{*}$ \\
& $(5,314)$ & $(86.21)$ & $(2.803)$ & $(1.361)$ \\
2 years after treatment & 8,853 & 297.8 & 11.61 & 3.236 \\
& $(9,589)$ & $(247.8)$ & $(7.771)$ & $(2.489)$ \\
3 years after treatment & $20,698 * *$ & $783.3 * * *$ & $22.41^{* *}$ & 2.509 \\
& $(8,630)$ & $(242.6)$ & $(9.587)$ & $(4.672)$ \\
\hline
\end{tabular}

Table 4A and 4B report estimation results from estimating models (4) and (5) respectively. Each observation corresponds to a customs and year from 1997 to 2008. "Customs Reform" is a treatment equal to 1 starting in the first year when more than $80 \%$ of imports were computerized in the custom associated to the plant. Controls include plant and year Fixed Effects, initial size of the customs interacted with year dummies. Standard errors clustered at customs level are in parenthesis. $* * * \mathrm{p}<0.01, * * \mathrm{p}<0.05, * \mathrm{p}<0.1$. 
Table 5: Effects of computerization on predictability of time to clear customs and tax rate

R-squared of Customs Clearance Time by treatment group

\begin{tabular}{ccccc}
\hline Year & $\begin{array}{c}\text { Non-Computerized } \\
\text { Customs }\end{array}$ & $\begin{array}{c}\text { Computerized } \\
\text { Customs }\end{array}$ & Difference & $\begin{array}{c}\text { p-value of } \\
\text { difference }\end{array}$ \\
\hline 2001 & $35.6 \%$ & $38.9 \%$ & $3.3 \%$ & 0.000 \\
2002 & $31.7 \%$ & $37.3 \%$ & $5.6 \%$ & 0.000 \\
2003 & $35.0 \%$ & $38.4 \%$ & $3.4 \%$ & 0.000 \\
2004 & $38.0 \%$ & $42.9 \%$ & $4.9 \%$ & 0.000 \\
$2001-04$ & $27.8 \%$ & $33.1 \%$ & $5.4 \%$ & 0.000 \\
\hline
\end{tabular}

We present, separately for each year and treatment group, the R2 when running the time to clear customs on net weight, fob value in pesos, custom dummies, firm dummies and dummies for category of product imported ( 2 digit classification). In these regressions the level of observation is the transaction. For each year, we present the difference between the $\mathrm{R} 2$ of treated and non treated group and the p-value of its significance estimated by bootstrap (1000 repetitions). 
Table 6A: Double Difference Estimation of the Effects of the Reform on Irregularities Related to Corruption at DIAN

\begin{tabular}{lcc}
\hline VARIABLES & $\begin{array}{c}\text { DIAN Corruption } \\
\text { Related Cases }\end{array}$ & $\begin{array}{c}\text { Factor of DIAN } \\
\text { Corruption Related } \\
\text { Cases }\end{array}$ \\
\hline Customs Reform & $-0.188^{* *}$ & $-0.368^{* *}$ \\
$(0.0744)$ & $(0.176)$ \\
Observations & 312 & 312 \\
Wild Bootstrap p-values & .0426 & .118 \\
Mean of outcome var. & 0.103 & 0 \\
\hline
\end{tabular}

Table 6B: Year by Year Estimation of the Effects of the Reform on on Irregularities Related to Corruption at DIAN

\begin{tabular}{lcc}
\hline VARIABLES & $\begin{array}{c}\text { DIAN Corruption } \\
\text { Related Cases }\end{array}$ & $\begin{array}{c}\text { Factor of DIAN } \\
\text { Corruption Related } \\
\text { Cases }\end{array}$ \\
\hline 2 years before treatment & -0.0394 & -0.177 \\
1 year before treatment & $(0.0795)$ & $(0.266)$ \\
1 year after treatment & 0.00295 & -0.0946 \\
2 years after treatment & $(0.0302)$ & $(0.180)$ \\
3 years after treatment & -0.0584 & -0.238 \\
& $(0.0776)$ & $(0.183)$ \\
& -0.117 & -0.876 \\
& $(0.0825)$ & $(0.668)$ \\
& $-0.398 *$ & $-0.743 *$ \\
\hline
\end{tabular}

Table 5A and 5B report estimation results from estimating models (4) and (5) respectively. Outcome variables are computed using the archive or irregularities from the Procuraduría General de la Nación (General Prosecutor). Each observation corresponds to a customs' municipality and year from 1997 to 2008. Controls include plant and year Fixed Effects, initial size of the customs interacted with year dummies. "Customs Reform" is a treatment equal to 1 starting in the first year when more than $80 \%$ of imports were computerized in the custom associated to the plant. Standard errors clustered at customs level are in parenthesis. $* * * p<0.01, * * p<0.05, * \mathrm{p}<0.1$. 


\section{APPENDIX}

Figure A1 Time to Clear Customs when Importing to Colombia

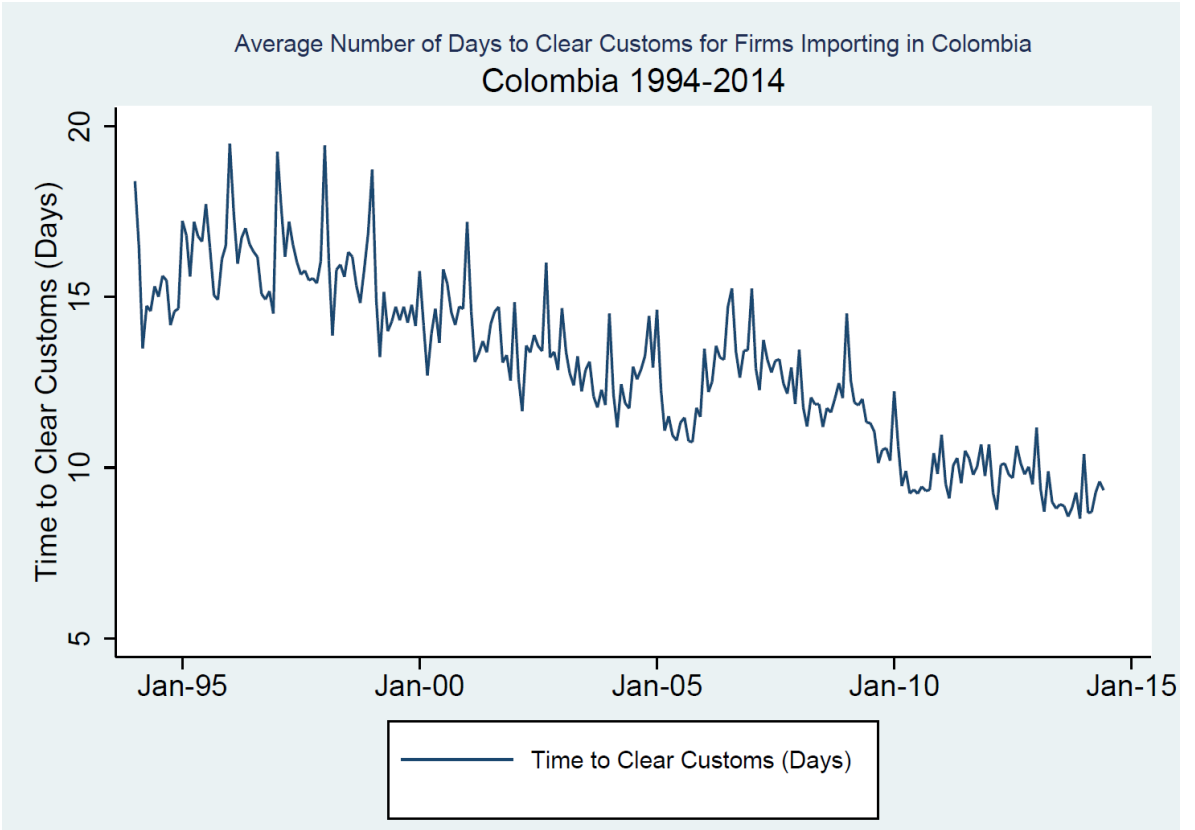

Figure A1 presents the average time to clear customs during an import transaction in Colombia. Using data from the DIAN from 1994 to 2014, we calculated by month, the average time all import transactions. 
Appendix Table 1: Definition of Variables

A1.A definition of variables from the Annual Manufacturing Surveys

\begin{tabular}{|c|c|}
\hline Variable & Description \\
\hline Customs Reform & $\begin{array}{l}\text { A dummy equal to one once the customs underwent the computerization ie after the first year with at least one } \\
\text { month with a proportion of import declarations made by computer that is bigger than } 80 \%\end{array}$ \\
\hline Exposure & $\begin{array}{l}\text { Dummy equal to } 1 \text { if the plant is exposed to the custom reform, i.e. if it imported a positive quantitiy in any year } \\
\text { between } 1997 \text { and } 1999\end{array}$ \\
\hline Inputs* & Inputs used by the plant, understood as all production factors other than capital and labor \\
\hline Sales* & Total revenue from sales, measured in millions of real pesos \\
\hline Value Added * & Sales from which the value of inputs is subrstracted \\
\hline Number of workers & Number of workers in the plant \\
\hline Capital* & Amount of capital in the plant. It includes: machines, equipment and transport equipment \\
\hline Value Added per Worker* & Value Added divided by the number of workers in the plant \\
\hline Export Dummy & Takes the value 1 if the plant exported a positive value that year or the sales abroad were positive \\
\hline TFP & Total Factor Productivity, calculated as a residuals with elasticity of inputs calculate by sector \\
\hline $\begin{array}{l}\text { Customs Initial Import } \\
\text { Value }\end{array}$ & FOB value that was imported in the assigned custom in 1999 \\
\hline
\end{tabular}

A1.B definition of variables from customs analyzed at plant level

Variable Description

Days of Customs Clearence Total time, in number of days, for a merchandise to go through the customs It is defined as: date of

Days of Customs Clearence authorization to leave - the date of the arrival

Paid/FOB Ratio between the amount that has been paid and the value of the merchandise

Tariff/FOB import value* Ratio between total amount that must be paid at the custom due tariff taxes and the FOB value

Paid/Due Ratio between what was paid and what has to be paid to the custom

Sanctions/FOB import value Value of payments due to delays and infractions during the importation process over the FOB value

Other/FOB import value Value of "Other payments", any payment other than taxes (VAT + Tariff) or sanctions, over the FOB value

A1.C definition of variables from customs analyzed at customs level

Variable

Customs Reform

Days to clear customs

Number of Imports

Total value of imports $(\mathrm{FOB})^{*}$

Total Transportation Costs* Transportation costs from departure abroad to the customs

Transport Costs/FOB Ratio between the tranportation costs and the value of the merchandise FOB

Total Taxes (VAT+Tariff)* Ratio of the sume between the total amount of Tariff Taxes and Value Added Taxes

Taxes Paid/FOB Ratio between the amount that has been paid to the customs and the value of the merchandise

A1.D definition of variables on irregularities from the Superintendency

Variable Description

Sum of the number of cases involving DIAN (Dirección de Impuestos y Aduanas Nacionales) of one of the

DIAN Corruption Related following types: administrative irregularities, contractual irregularities, budget irregularities and irregularities

Cases with criminal connotations. The listing of irregularities related to corruption comes from the Procuraduria General de la Nacion.

Number of corruption cases Sum of the 4 types of cases mentioned above, but NOT involving the DIAN.

other than DIAN

Factor of DIAN Corruption
Related Cases*

Factor of corruption cases First Factor of the 4 types of cases mentioned above, but NOT involving the DIAN

*ther than DIAN*

All monetary values are expressed in millions of real pesos per year and are deflated by PPI (1988). 
Table A2: Effects of Customs Reform * Exposure estimated on firms outcomes excluding customs one by one

\begin{tabular}{|c|c|c|c|c|c|c|c|c|c|}
\hline $\begin{array}{l}\text { Excluded } \\
\text { Customs } \\
\end{array}$ & Inputs & Sales & Value Added & $\begin{array}{c}\begin{array}{c}\text { Number of } \\
\text { workers }\end{array} \\
\end{array}$ & Capital & $\begin{array}{l}\text { Value Added } \\
\text { per Worker }\end{array}$ & $\begin{array}{l}\text { Export } \\
\text { dummy }\end{array}$ & TFP & $\begin{array}{c}\mathrm{Nb} \text { of } \\
\text { obs. }\end{array}$ \\
\hline$\overline{\text { Bogotá }}$ & $\begin{array}{l}0.085^{* * *} \\
(0.032)\end{array}$ & $\begin{array}{c}0.133^{* * * *} \\
(0.024)\end{array}$ & $\begin{array}{c}0.186^{* * * * *} \\
(0.035)\end{array}$ & $\begin{array}{c}0.09^{* * * *} \\
(0.026)\end{array}$ & $\begin{array}{c}0.065 \\
(0.050)\end{array}$ & $\begin{array}{c}0.097 * * * * \\
(0.025)\end{array}$ & $\begin{array}{c}0.031 \\
(0.020)\end{array}$ & $\begin{array}{l}0.04 * * * \\
(0.011)\end{array}$ & 19,056 \\
\hline Medellin & $\begin{array}{c}0.071^{* *} \\
(0.024)\end{array}$ & $\begin{array}{l}0.084^{* * *} \\
(0.027)\end{array}$ & $\begin{array}{c}0.132 * * * * \\
(0.033)\end{array}$ & $\begin{array}{l}0.053^{* *} \\
(0.019)\end{array}$ & $\begin{array}{c}0.049 \\
(0.033)\end{array}$ & $\begin{array}{c}0.079 * * * \\
(0.021)\end{array}$ & $\begin{array}{l}0.088^{*} \\
(0.041)\end{array}$ & $\begin{array}{l}0.018 * * \\
(0.0063)\end{array}$ & 33,924 \\
\hline Cali & $\begin{array}{c}0.063^{* * * *} \\
(0.018)\end{array}$ & $\begin{array}{c}0.086^{* * * * *} \\
(0.024)\end{array}$ & $\begin{array}{c}0.131^{* * * *} \\
(0.027)\end{array}$ & $\begin{array}{c}0.057^{* * *} \\
(0.017)\end{array}$ & $\begin{array}{c}0.03 \\
(0.024)\end{array}$ & $\begin{array}{c}0.074 * * * * \\
(0.017)\end{array}$ & $\begin{array}{l}0.088^{* * *} \\
(0.034)\end{array}$ & $\begin{array}{l}0.024 * * \\
(0.0095)\end{array}$ & 40,140 \\
\hline Barranquilla & $\begin{array}{c}0.06^{* * * *} \\
(0.016)\end{array}$ & $\begin{array}{l}0.08^{* * * *} \\
(0.022)\end{array}$ & $\begin{array}{c}0.124 * * * \\
(0.024)\end{array}$ & $\begin{array}{c}0.052^{* * * *} \\
(0.015)\end{array}$ & $\begin{array}{c}0.024 \\
(0.020)\end{array}$ & $\begin{array}{c}0.072^{* * * *} \\
(0.017)\end{array}$ & $\begin{array}{l}0.092 * * \\
(0.033)\end{array}$ & $\begin{array}{c}0.026^{* * *} \\
(0.010)\end{array}$ & 39,408 \\
\hline Cartagena & $\begin{array}{c}0.077^{* * * *} \\
(0.020)\end{array}$ & $\begin{array}{c}0.093^{* * * *} \\
(0.027)\end{array}$ & $\begin{array}{c}0.138^{* * * *} \\
(0.030)\end{array}$ & $\begin{array}{c}0.067^{* * * *} \\
(0.019)\end{array}$ & $\begin{array}{c}0.031 \\
(0.024)\end{array}$ & $\begin{array}{c}0.07 * * * \\
(0.016)\end{array}$ & $\begin{array}{c}0.089^{* * *} \\
(0.034)\end{array}$ & $\begin{array}{c}0.024^{* *} \\
(0.0098)\end{array}$ & 39,576 \\
\hline Buenaventura & $\begin{array}{c}0.065^{* *} \\
(0.022)\end{array}$ & $\begin{array}{c}0.084^{* * *} \\
(0.026)\end{array}$ & $\begin{array}{c}0.127^{* * * *} \\
(0.026)\end{array}$ & $\begin{array}{l}0.062^{* * *} \\
(0.021)\end{array}$ & $\begin{array}{c}0.029 \\
(0.027)\end{array}$ & $\begin{array}{c}0.065^{* * * *} \\
(0.012)\end{array}$ & $\begin{array}{l}0.091 \text { *** } \\
(0.036)\end{array}$ & $\begin{array}{l}0.022 * * \\
(0.0089)\end{array}$ & 37,944 \\
\hline Cúcuta & $\begin{array}{c}0.06^{* * * *} \\
(0.016)\end{array}$ & $\begin{array}{c}0.084^{* * * * *} \\
(0.024)\end{array}$ & $\begin{array}{c}0.131^{* * * *} \\
(0.028)\end{array}$ & $\begin{array}{c}0.054^{* * *} \\
(0.016)\end{array}$ & $\begin{array}{c}0.027 \\
(0.022)\end{array}$ & $\begin{array}{c}0.077^{* * * *} \\
(0.018)\end{array}$ & $\begin{array}{c}0.086^{* * *} \\
(0.034)\end{array}$ & $\begin{array}{c}0.027^{* * *} \\
(0.0098)\end{array}$ & 41,052 \\
\hline Ipiales & $\begin{array}{c}0.063 * * * \\
(0.017)\end{array}$ & $\begin{array}{c}0.083 * * * \\
(0.022)\end{array}$ & $\begin{array}{c}0.125 * * * \\
(0.023)\end{array}$ & $\begin{array}{c}0.055^{* * *} \\
(0.016)\end{array}$ & $\begin{array}{c}0.03 \\
(0.023)\end{array}$ & $\begin{array}{c}0.07 * * * \\
(0.015)\end{array}$ & $\begin{array}{c}0.085^{* *} \\
(0.034)\end{array}$ & $\begin{array}{l}0.024 * * \\
(0.0092)\end{array}$ & 41,364 \\
\hline Santa Marta & $\begin{array}{c}0.067 * * * \\
(0.019)\end{array}$ & $\begin{array}{c}0.087 * * * \\
(0.024)\end{array}$ & $\begin{array}{c}0.132 * * * \\
(0.027)\end{array}$ & $\begin{array}{c}0.057^{* * *} \\
(0.017)\end{array}$ & $\begin{array}{c}0.03 \\
(0.023)\end{array}$ & $\begin{array}{c}0.074 * * * \\
(0.017)\end{array}$ & $\begin{array}{c}0.084 * * \\
(0.034)\end{array}$ & $\begin{array}{l}0.025 * * \\
(0.0096)\end{array}$ & 41,496 \\
\hline Pereira & $\begin{array}{c}0.066^{* * * *} \\
(0.018)\end{array}$ & $\begin{array}{c}0.087 * * * \\
(0.024)\end{array}$ & $\begin{array}{c}0.133^{* * * *} \\
(0.027)\end{array}$ & $\begin{array}{c}0.058^{* * *} \\
(0.018)\end{array}$ & $\begin{array}{c}0.032 \\
(0.024)\end{array}$ & $\begin{array}{c}0.075^{* * * *} \\
(0.017)\end{array}$ & $\begin{array}{c}0.084 * * \\
(0.034)\end{array}$ & $\begin{array}{l}0.025^{* * *} \\
(0.0095)\end{array}$ & 41,664 \\
\hline
\end{tabular}

Table A2 reports estimation of the triple difference results from estimating models (1) excluding, in each case the customs in column 1 . Each observation corresponds to a plant and year. The data before excluding customs includes all (the 3,478) manufacturing plants in Colombia that were available in the manufacturing data from 1997 to 2008. "Customs Reform" is the treatment, equal to 1 when more than $80 \%$ of import transactions were computerized in the custom associated to the plant. "Exposure" is a dummy equal to 1 if the corresponding firm exported at least once between 1997 and 1999. All values are expressed logs. Controls include plant and year Fixed Effects, initial log of value added of the plant interacted with year dummies and initial log of size of the customs interacted with year dummies. Standard errors clustered at customs level are in parenthesis. $* * * \mathrm{p}<0.01, * * \mathrm{p}<0.05, * \mathrm{p}<0.1$. 
Table A3: Effect of Computerization on Plants' Economic Activity using a Continuous Treatment Based on Fraction of Customs Treated

\begin{tabular}{|c|c|c|c|c|c|c|c|c|}
\hline VARIABLES & Log Inputs & Log Sales & $\begin{array}{c}\text { Log Value } \\
\text { Added }\end{array}$ & $\begin{array}{c}\text { Log Number } \\
\text { of workers }\end{array}$ & Log Capital & $\begin{array}{c}\text { Log Value } \\
\text { Added per } \\
\text { Worker } \\
\end{array}$ & Export dummy & TFP \\
\hline Exposure * Customs Reform & $\begin{array}{c}0.104 * * * \\
(0.032)\end{array}$ & $\begin{array}{c}0.138 * * * \\
(0.028)\end{array}$ & $\begin{array}{c}0.189 * * * \\
(0.030)\end{array}$ & $\begin{array}{c}0.101 * * * \\
(0.023)\end{array}$ & $\begin{array}{c}0.045 \\
(0.031)\end{array}$ & $\begin{array}{c}0.088^{* * *} * \\
(0.023)\end{array}$ & $\begin{array}{c}0.069 * * * \\
(0.012)\end{array}$ & $\begin{array}{c}0.031 * * * \\
(0.010)\end{array}$ \\
\hline Customs Reform & $\begin{array}{l}-0.006 \\
(0.037)\end{array}$ & $\begin{array}{l}-0.042 \\
(0.031)\end{array}$ & $\begin{array}{l}-0.062 * \\
(0.037)\end{array}$ & $\begin{array}{l}-0.024 \\
(0.028)\end{array}$ & $\begin{array}{c}-0.04 \\
(0.035)\end{array}$ & $\begin{array}{l}-0.038 \\
(0.034)\end{array}$ & $\begin{array}{l}-0.026 \\
(0.023)\end{array}$ & $\begin{array}{l}-0.007 \\
(0.014)\end{array}$ \\
\hline $\begin{array}{l}\text { Observations } \\
\text { p-val of sum of both coef. }\end{array}$ & $\begin{array}{l}41,314 \\
0.0049\end{array}$ & $\begin{array}{l}41,314 \\
0.0009\end{array}$ & $\begin{array}{l}41,254 \\
0.0003\end{array}$ & $\begin{array}{l}41,314 \\
0.0027\end{array}$ & $\begin{array}{l}41,314 \\
0.8672\end{array}$ & $\begin{array}{l}41,254 \\
0.1272\end{array}$ & $\begin{array}{l}41,314 \\
0.0685\end{array}$ & $\begin{array}{l}41,314 \\
0.0782\end{array}$ \\
\hline
\end{tabular}

Table A4: Effects of Computerization on Plants' Economic Activity when Plants are Matched with Customs Based on Most Likely Origin of it Inputs in 1999

\begin{tabular}{|c|c|c|c|c|c|c|c|c|}
\hline VARIABLES & Log Inputs & Log Sales & $\begin{array}{l}\text { Log Value } \\
\text { Added }\end{array}$ & $\begin{array}{l}\text { Log Number } \\
\text { of workers }\end{array}$ & Log Capital & $\begin{array}{l}\text { Log Value } \\
\text { Added per } \\
\text { Worker } \\
\end{array}$ & Export dummy & TFP \\
\hline Exposure * Customs Reform & $\begin{array}{c}0.105 * * * \\
(0.033)\end{array}$ & $\begin{array}{c}0.147 * * * \\
(0.028)\end{array}$ & $\begin{array}{c}0.191 * * * \\
(0.031)\end{array}$ & $\begin{array}{c}0.111 * * * \\
(0.023)\end{array}$ & $\begin{array}{c}0.046 \\
(0.031)\end{array}$ & $\begin{array}{c}0.081 * * * \\
(0.023)\end{array}$ & $\begin{array}{c}0.059 * * * \\
(0.012)\end{array}$ & $\begin{array}{c}0.032 * * * \\
(0.010)\end{array}$ \\
\hline Customs Reform & $\begin{array}{c}0.153 * * * \\
(0.045)\end{array}$ & $\begin{array}{c}0.065 \\
(0.040)\end{array}$ & $\begin{array}{l}-0.074 \\
(0.047)\end{array}$ & $\begin{array}{c}0.006 \\
(0.032)\end{array}$ & $\begin{array}{c}-0.112^{* *} \\
(0.050)\end{array}$ & $\begin{array}{c}-0.079 * * \\
(0.037)\end{array}$ & $\begin{array}{c}0.123 * * * \\
(0.018)\end{array}$ & $\begin{array}{c}0.012 \\
(0.013)\end{array}$ \\
\hline $\begin{array}{l}\text { Observations } \\
\text { p-val of sum of both coef. }\end{array}$ & $\begin{array}{l}41,460 \\
0.0000\end{array}$ & $\begin{array}{l}41,460 \\
0.0000\end{array}$ & $\begin{array}{l}41,398 \\
0.0060\end{array}$ & $\begin{array}{l}41,460 \\
0.0001\end{array}$ & $\begin{array}{l}41,460 \\
0.1274\end{array}$ & $\begin{array}{l}41,398 \\
0.9526\end{array}$ & $\begin{array}{l}41,460 \\
0.0000\end{array}$ & $\begin{array}{l}41,460 \\
0.0001\end{array}$ \\
\hline
\end{tabular}


Table A5: Effect of computerization on imports level outcomes, separating firms by quartile of value added in 1999

\begin{tabular}{|c|c|c|c|c|c|}
\hline $\begin{array}{l}\text { Quartile (of } \\
\text { VA in 1999) } \\
\end{array}$ & VARIABLE (log): & $\begin{array}{c}\text { Custom } \\
\text { Clearence Time }\end{array}$ & Paid/FOB & Paid/Due & $\begin{array}{l}\text { Sanctions/FOB } \\
\text { import value }\end{array}$ \\
\hline \multirow{2}{*}{$\begin{array}{c}\text { Quartile 1 } \\
\text { (Exposure = } \\
23 \%)\end{array}$} & Customs Reform & $\begin{array}{l}-0.475 \\
(1.54)\end{array}$ & $\begin{array}{c}0.021 \\
(0.022)\end{array}$ & $\begin{array}{c}0.034 \\
(0.021)\end{array}$ & $\begin{array}{c}0.00001 \\
(5.69 \mathrm{e}-06)\end{array}$ \\
\hline & Mean of outcome var & 14.30 & 0.0321 & 0.968 & $2.23 \mathrm{e}-05$ \\
\hline \multirow{2}{*}{$\begin{array}{c}\text { Quartile } 2 \\
\text { (Exposure }= \\
43 \%)\end{array}$} & Customs Reform & $\begin{array}{l}-0.169 \\
(0.42)\end{array}$ & $\begin{array}{c}-0.021 * * * \\
(0.0049)\end{array}$ & $\begin{array}{c}0.006 \\
(0.012)\end{array}$ & $\begin{array}{c}0.0001 \\
(0.000076)\end{array}$ \\
\hline & Mean of outcome var & 14.85 & 0.0357 & 0.974 & $3.55 \mathrm{e}-05$ \\
\hline \multirow{2}{*}{$\begin{array}{c}\text { Quartile } 3 \\
\text { (Exposure = } \\
76 \%)\end{array}$} & Customs Reform & $\begin{array}{l}0.673 \\
(0.68)\end{array}$ & $\begin{array}{c}0.001 \\
(0.015)\end{array}$ & $\begin{array}{c}0.013 \\
(0.012)\end{array}$ & $\begin{array}{c}0.00005 \\
(0.000030)\end{array}$ \\
\hline & Mean of outcome var & 15.14 & 0.0384 & 0.946 & $4.02 \mathrm{e}-05$ \\
\hline $\begin{array}{c}\text { Quartile } 4 \\
\text { (Exposure }= \\
95 \%) \\
\end{array}$ & Customs Reform & $\begin{array}{c}-1.525 * * * \\
(0.30) \\
1529\end{array}$ & $\begin{array}{c}0.002 \\
(0.0017) \\
0.0302\end{array}$ & $\begin{array}{c}0.058 * * \\
(0.020) \\
0762\end{array}$ & $\begin{array}{c}0.00002 * * \\
(6.34 \mathrm{e}-06) \\
369 \mathrm{e}-05\end{array}$ \\
\hline \multicolumn{6}{|c|}{$\begin{array}{l}\text { Table A5 reports estimation results from estimating model (3) separately for each quartile of value added of plants in } 1999 \text {. Each } \\
\text { observation corresponds to a firm and year. It includes all (the 1,837) manufacturing firms in Colombia that could be matched to } \\
\text { the customs data, and available from } 1997 \text { to } 2008 \text {. "Customs Reform" is a treatment dummy equal to } 1 \text { starting the first year } \\
\text { when more than } 80 \% \text { of import transactions were computerized in the customs associated to the plant. Controls include plant } \\
\text { and year Fixed Effects, initial log of value added of the plant interacted with year dummies and initial log of size of the customs } \\
\text { interacted with year dummies. Observations are weighted by the value added of the firm in } 1999 \text {, before any reform started. } \\
\text { Standard errors clustered at customs level are in parenthesis. }{ }^{* * *} p<0.01 \text {, }{ }^{* *} p<0.05,{ }^{*} p<0.1 \text {. }\end{array}$} \\
\hline
\end{tabular}

